\title{
Hippocampal pyramidal cells: the reemergence of cortical lamination
}

\author{
Lutz Slomianka • Irmgard Amrein • \\ Irene Knuesel · Jens Christian Sørensen • \\ David P. Wolfer
}

Received: 11 March 2011 / Accepted: 26 April 2011/Published online: 20 May 2011

(C) The Author(s) 2011. This article is published with open access at Springerlink.com

\begin{abstract}
The increasing resolution of tract-tracing studies has led to the definition of segments along the transverse axis of the hippocampal pyramidal cell layer, which may represent functionally defined elements. This review will summarize evidence for a morphological and functional differentiation of pyramidal cells along the radial (deep to superficial) axis of the cell layer. In many species, deep and superficial sublayers can be identified histologically throughout large parts of the septotemporal extent of the hippocampus. Neurons in these sublayers are generated during different periods of development. During development, deep and superficial cells express genes (Sox5, SatB2) that also specify the phenotypes of superficial and deep cells in the neocortex. Deep and superficial cells differ neurochemically (e.g. calbindin and zinc) and in their adult gene expression patterns. These markers also distinguish sublayers in the septal hippocampus, where they are not readily apparent histologically in rat or mouse. Deep and superficial pyramidal cells differ in septal, striatal, and neocortical efferent connections. Distributions of deep
\end{abstract}

L. Slomianka $(\bowtie) \cdot$ I. Amrein · D. P. Wolfer

Institute of Anatomy, University of Zürich,

8057 Zürich, Switzerland

e-mail: slomianka@anatom.uzh.ch

I. Knuesel

Institute of Pharmacology and Toxicology, University of Zürich, Zürich, Switzerland

J. C. Sørensen

Department of Neurosurgery, Aarhus University Hospital,

Aarhus, Denmark

D. P. Wolfer

Institute of Anatomy and Zürich Center for Integrative Human Physiology, University of Zürich and Institute of Human Movement Sciences, ETH Zürich, Zürich, Switzerland and superficial pyramidal cell dendrites and studies in reeler or sparsely GFP-expressing mice indicate that this also applies to afferent pathways. Histological, neurochemical, and connective differences between deep and superficial neurons may correlate with (patho-) physiological phenomena specific to pyramidal cells at different radial locations. We feel that an appreciation of radial subdivisions in the pyramidal cell layer reminiscent of lamination in other cortical areas may be critical in the interpretation of studies of hippocampal anatomy and function.

Keywords Hippocampus - CA1 - CA3 - Afferent pathways - Calbindin - Efferent pathways .

Development $\cdot$ Physiology $\cdot$ Zinc

\section{Introduction}

Traditionally the hippocampal pyramidal cell layer is divided into a number of subfields along its transverse extent from its proximal end close to the area dentata to its distal limit adjacent to the subiculum. On the basis of the absence or presence of the layer harboring the mossy fibers, the earliest subdivision recognized two fields, regio superior and regio inferior (Ramón y Cajal 1893). Later Golgistudies refined this division, resulting in the recognition of several subfields and adoption of the CA1a-c-CA2-CA3ac nomenclature (Lorente de Nó 1934). The topographical organization of projections from CA3 to CA1 (Ishizuka et al. 1990), from CA1 to the subiculum (Tamamaki and Nojyo 1991; Tamamaki et al. 1987; Amaral et al. 1991) and, finally, from CA1 and the subiculum to extrahippocampal sites (Witter et al. 1990; Namura et al. 1994; Tamamaki and Nojyo 1995; Risold and Swanson 1996; Blatt and Rosene 1998) have given credence to the 
existence of functionally different subfields although they may not strictly correspond to the a-c subfields recognized in earlier Golgi studies. It appears that “... information processing from one field to the next in the hippocampal formation follows channels formed by subsets of neurons in different proximodistal portions of each field" (Amaral 1993). Connectional evidence for a distinction of information channels has been elaborated upon by gene expression studies of hippocampal pyramidal cells. Distinct gene expression patterns can be found along the septotemporal axis of the hippocampal fields (Thompson et al. 2008; Fanselow and Dong 2010; Dong et al. 2009) and, at a particular septotemporal level, in different segments of the CA3 pyramidal cell (Thompson et al. 2008). Thus, the concept of a functional and morphological division along the transverse axis (or in the tangential plane), which we know so well from the neocortex, seems to also apply to the fields of the archicortical hippocampus.

A second concept of neocortical organization - that of a radial subdivision in cell layers tiered from the white matter at depth to the pia-is not recognized in the hippocampus. While layers harboring polymorphic (inter-) neurons are sometimes understood as separate cell layers, the bulk of the cells, hippocampal pyramidal cells, are largely thought of as a homogeneous population, which forms one lamina, the pyramidal cell layer, which is not further divided along its radial axis. Based on a brief review of the histology, development, neurochemistry, and connectivity of the pyramidal cell layer, with some emphasis on CA1, we will discuss (1) if this view is still tenable, (2) which subdivision may be suggested, and (3) what implications such a subdivision may have for our understanding of hippocampal function.

\section{Nomenclature}

We follow Ishizuka et al. (1990) and use the terms proximal (nearer the dentate gyrus) and distal (further away from the dentate gyrus) to designate positions along the transverse axis of the CA1 and CA3. The terms septal (closer, by way of the fimbria, to the septum) and temporal (further away from the septum) are used to designate positions along the longitudinal axis of the hippocampus. This nomenclature is independent of differences in position that accompany phylogenetic changes in the size and shape of the adjacent cortical areas. Molecular and connectional criteria have replaced the original definition of CA2 based on Golgi stains (Lein et al. 2005). With one exception (see Neurochemistry), we did not find evidence that would distinguish this field from CA1 as far as lamination is concerned, and it is here treated as the part of CA1. For the sake of simplicity, we use "CA1" throughout instead of the
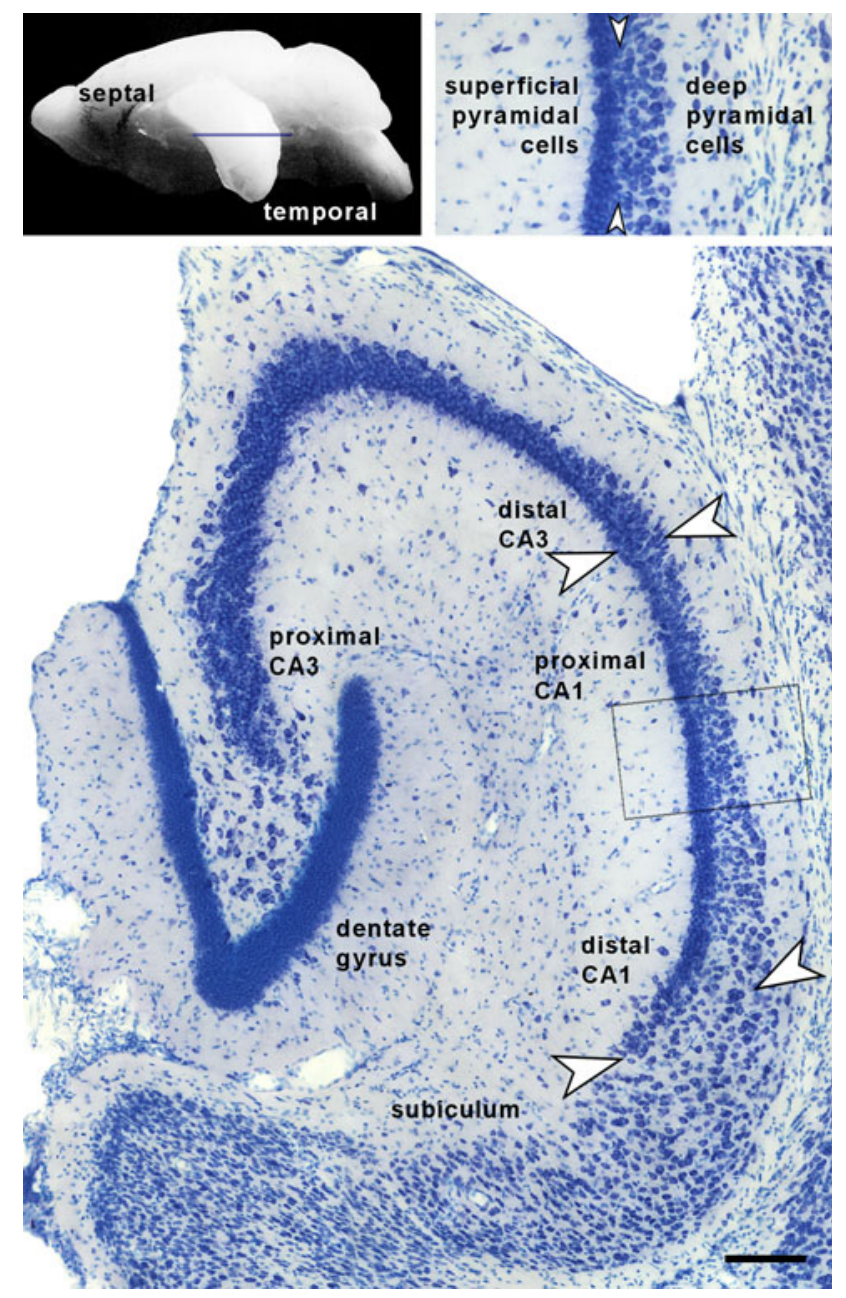

Fig. 1 Illustration of the nomenclature used in this review. The top left inset shows the hippocampus of one hemisphere from which nonhippocampal tissue had been removed and illustrates the terms "septal" and "temporal". The approximately mid-septotemporal location of the main image of a horizontal section is indicated in the top left inset by a line. The main image illustrates the terms "proximal" and "distal". The proximal border of CA1 (more correctly CA1/2) towards CA 3 and between distal CA1 and the subiculum is marked by arrowheads. The top right inset shows the pyramidal cells marked in the main image and illustrates the use of the terms "superficial" and "deep". Scalebar $100 \mu \mathrm{m}$

more correct "CA1/2". Terms and definitions are illustrated in Fig. 1.

\section{Histology}

Cortical layers can be defined on the basis of the types of cells that are found in a particular layer and/or the spatial distribution and density of the types within a layer. For both of these criteria early descriptions suggest subdivisions of the CA1 pyramidal cell layer. Looking at cell types, Schaffer (1892) understood the pyramidal cell layer 
as the merger of two layers that also characterize the adjacent subiculum: a deep layer containing large pyramidal cells and superficial layer composed of small pyramidal cells. Lorente de Nó (1934) instead focused on spatial distribution: “.... There are two types of pyramids, superficial and deep ones. The superficial are arranged in one or two very dense rows. The deep pyramids are grouped into several less dense rows below .... It is important to distinguish both types of pyramids for two reasons. One is that the deep pyramids are less numerous in lower mammals (mouse, rabbit, dog, cat) than in primates (monkey, man)." His second reason, pertaining to connections between pyramidal cells and basket cells, will be discussed in the section on afferent connections.

Phylogenetic differences in the distribution of pyramidal cells were also recognized by Stephan (1975) in his extensive review of the allocortex. Based on the increasing number of deep pyramidal cells in species which may represent stages of primate evolution from insectivores to humans and the concomitant dissolution of the compact, superficial cell rows, Stephan suggested a progressive "invasion" of the stratum oriens by pyramidal cells, which, in a hypothetical ancestor, were located in a compact cell layer. This appealing phylogenetic interpretation of CA1 cytoarchitecture in primates (e.g. human, Fig. 2a; marmoset monkey, Fig. 2b) has somewhat distracted attention from the fact that a substantial portion of stratum oriens is occupied by pyramidal cells in species as taxonomically diverse as duck-billed platypus (Ornithorhynchus anatinus, Rose 1926), the small Australian marsupial Parma wallaby (Macropus parma, Fig. 2f) and common brush-tailed possum (Trichosurus vulpecula, Fig. 2g), the Guaira spiny rat (Proechimys guaira, Scorza et al. 2011), pig (Sus scrofa, Schaffer 1892; Holm and Geneser 1991), dog (Canis lupus familiaris, Rose 1926; Hof et al. 1996), fox (Vulpes vulpes, Fig. 2h), and bottlenose dolphin (Tursiops truncatus, Jacobs et al. 1979). In these species, spanning all mammalian subclasses and representatives in major orders, the "invasion" of stratum oriens is not accompanied by a dissolution of the denser, superficial rows of CA1 pyramidal cells.

A cytoarchitectural presentation of CA1 similar to that seen in primates can be found in microchiropteran bats. While some condensation of superficial pyramidal cells is still visible in the large-eared slit-faced bat (Nycteris macrotis, Fig. 2c) a fairly homogeneous distribution of cells can be seen in the little free-tailed bat (Chaerephon pumilus, Fig. 2d). While many similar examples can be found among microchiropteran bats (I. Amrein, unpublished observations), CA1 is split into two fairly compact layers in the Burmese whiskered bat (Myotis montivagus, Baron et al. 1996) resembling the appearance to CA1 in reeler mice (see below, Development). A bilaminar CA1 is also seen in the common mole rat (Cryptomys hottentotus, Fig. 2i), a member of the mole rat family (Bathyergidae). In contrast to microchiropteran bats, a rather wide but otherwise inconspicuous CA1 is found in some megachiropteran fruit bats (Epomorphus wahlbergi: Fig. 2e, Rousettus amplexicaudatus: Baron et al. 1996, Pteropus scapulatus: Buhl and Dann 1991).

Cytoarchitectural differences between the mentioned species can be understood as an "invasion" of stratum oriens in which either only deep pyramidal cells or both deep and superficial pyramidal cells participate. Deep and superficial pyramids seem, to some degree, to be independent in their participation in this process. It is also noteworthy that two sublayers, which differ in the cell sizes and packing density, can still be identified in the human CA1 (Fig. 2a, Braak 1974) although it may require unusually thick sections to ascertain small differences in cell densities. Braak (1974) applied the terms "stratum superficiale" and "stratum profundum" to these sublayers, which also have been rendered visible in diffusion tensor images of the human hippocampus (Shepherd et al. 2007). A laminar division is more clearly visible in the part of the monkey pyramidal cell layer identified as CA2 by Rosene and van Hoesen (1987). Also, in one case (11/16) reported by Sloviter et al. (2004), an astounding subdivision of the human CA1 pyramidal cell layer into two tiers was observed.

Can two sublayers be identified in all species and, in particular, are they present in mouse and rat? CA1 pyramidal cells form a compact layer without an apparent subdivision throughout much of the septotemporal extent of the eastern rock elephant shrew (Elephantulus myurus, Fig. 2j), chinchilla (Chinchilla laniger, Fig. 2k), guinea pig (Cavia porcellus), and rabbit (Oryctolagus cuniculus) hippocampus (Geneser-Jensen et al. 1974; Geneser 1987). A similar appearance is seen in approximately the septal one-third of the rat (Fig. 21) and mouse hippocampus (Fig. 20). The division into deep and superficial layers that becomes apparent further temporally can, however, be identified in fortuitous sections (Fig. 2m) and, more regularly, in the distal part of the septal CA1. Further temporally, an easily visible sublayer of loosely arranged pyramidal cells becomes first apparent distally. Two histologically distinct sublayers are visible along the proximodistal extent of CA1 (except for a very narrow sector at the proximal limit) throughout most of the temporal two-thirds of the hippocampus of the rat and mouse (Fig. 2n, p). A distinction of two sublayers in CA1 as a characteristic of some parts of the mouse hippocampus was recognized by Rose (1926), and a division of the layer was also mentioned by Ramón y Cajal (1893). In the rat, the division appears sufficiently striking in Nissl-stained preparations to be illustrated throughout the septotemporal extent of CA1 in the atlas of Swanson (1992), but not in the widely used atlas of Paxinos and Watson (1986). Also, a radial division of the layer was not mentioned in the germinal works of 


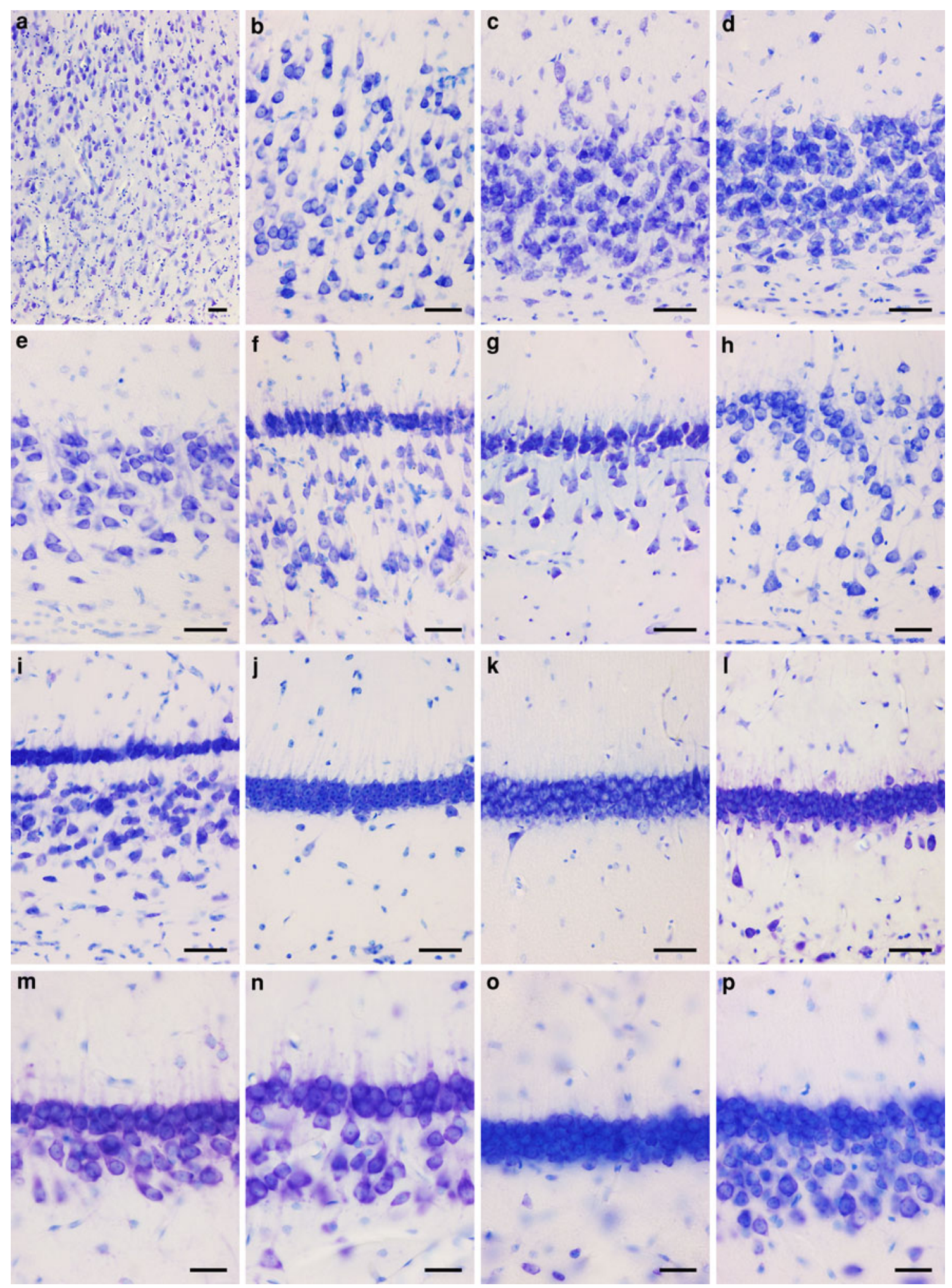

Fig. 2 Nissl-stained CA1 pyramidal cell layer. Unless noted otherwise, images were taken at mid-proximodistal and mid-septotemporal locations. a Human, slight differences between superficial and deep CA1 can be seen in both cell density and staining characteristics of the pyramidal cells, b Marmoset monkey, c large-eared slit-faced bat, d little free-tailed bat, e Wahlberg's epauletted fruit bat, f Parma wallaby, $\mathbf{g}$ common brush-tailed possum, $\mathbf{h}$ fox, $\mathbf{i}$ common mole rat, j eastern rock elephant shrew, $\mathbf{k}$ long-tailed chinchilla, l-n Wistar rat, $\mathbf{l}$ septal, $\mathbf{m}$ septal extreme and $\mathbf{n}$ temporal CA1, o-p C57BL/6 mouse, o septal and p temporal CA1. Scalebars $\mathbf{a}-\mathbf{l} 50 \mu \mathrm{m}, \mathbf{m}-\mathbf{p} 25 \mu \mathrm{m}$ 
Krieg (1946) and Blackstad (1956), which may in part explain the lack of attention to its possible existence.

\section{Development}

Neurogenesis of hippocampal pyramidal cells occurs mainly during gestational days 17-19 in rats (Schlessinger et al. 1978; Bayer 1980) and days 14-16 in mice (Angevine 1965; Caviness 1973; Stanfield and Cowan 1979a; Smart 1982). CA1 pyramidal cells that originate at particular times during these periods are found at specific radial locations in the cell layer of the adult animal, following the "inside-out" pattern typical for other cortical areas. Neurons formed early are found at depth in the cell layer. Cells generated later form the dense superficial band of pyramids. The situation is somewhat more complex in CA3 due to the extended route of migration of pyramidal cells from their ventricular germinative zone to the developing extraventricular part of CA3 (Altman and Bayer 1990). A proximal (early) to distal (late) pattern of CA3 pyramidal cell generation is superimposed on the "inside-out" pattern (Angevine 1965; Bayer 1980; Smart 1982).

\section{CA1}

Morphological differences between cells at different radial locations in the pyramidal cell layer and the maintenance of spatial relations according to neuronal birthdays may still be accommodated within the idea that the pyramidal cells are a radially homogeneous population of neurons. However, a migration defect in reeler mice does not result in a simple "inside-out" to "outside-in" reversal. Neither does this mutation result in the random scattering of cells that is observed for the dentate granule cells. Instead pyramidal cells are sorted, according to their time of generation, into two, more or less distinct, sublayers (Fig. 3a-e; Caviness 1973; Stanfield and Cowan 1979a, b; Deller et al. 1999; Coulin et al. 2001). Early born cells concentrate in a layer close to the alveus. This layer is separated by a cell-sparse zone from a layer formed by lately born cells closer to the obliterated hippocampal fissure.
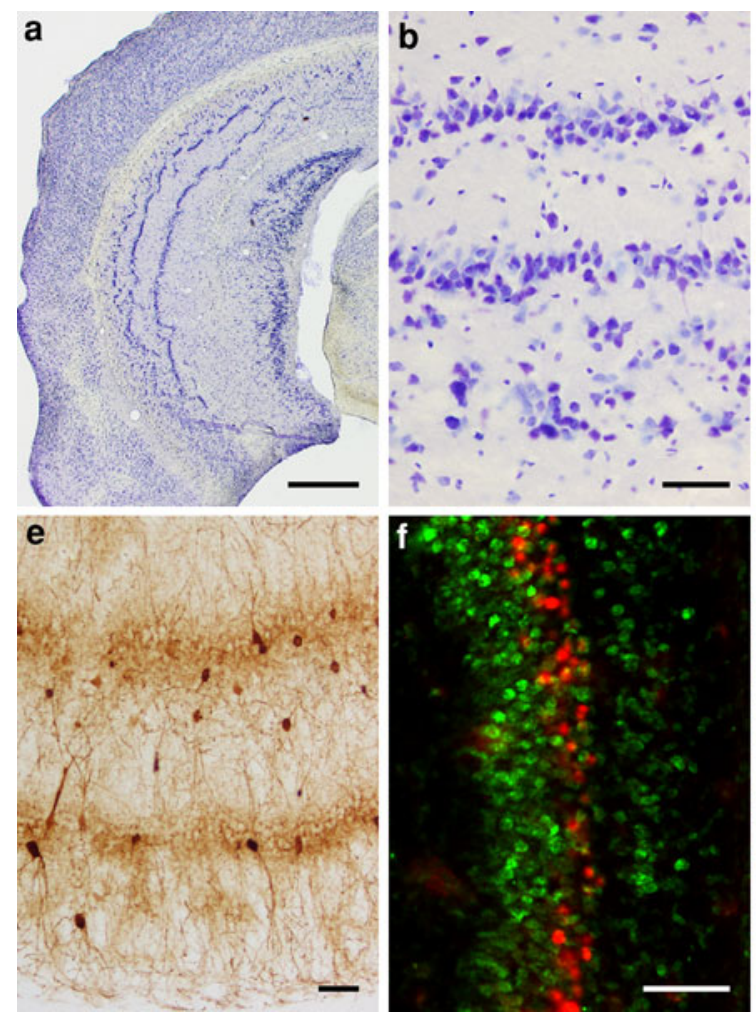

Fig. 3 a Hippocampus of a mouse carrying the Reln ${ }^{\text {orl }}$ reelin mutation. b Two distinct cell layers and deep cell clusters in the septal mid-proximodistal CA1 of a $\operatorname{Reln}^{\text {orl }}$ mouse. c At more temporal levels packing densities and cell sizes in the two CA1 layers resemble those in normal laboratory mice. d CA1 pyramidal cells in Reln ${ }^{\text {orl }}$ mouse retain their neurochemical identity with regard to calbindin, with only the younger, now deep pyramids showing moderate calbindin immunoreactivity. e The two CA1 layers of Reln ${ }^{\text {orl }}$ mice do

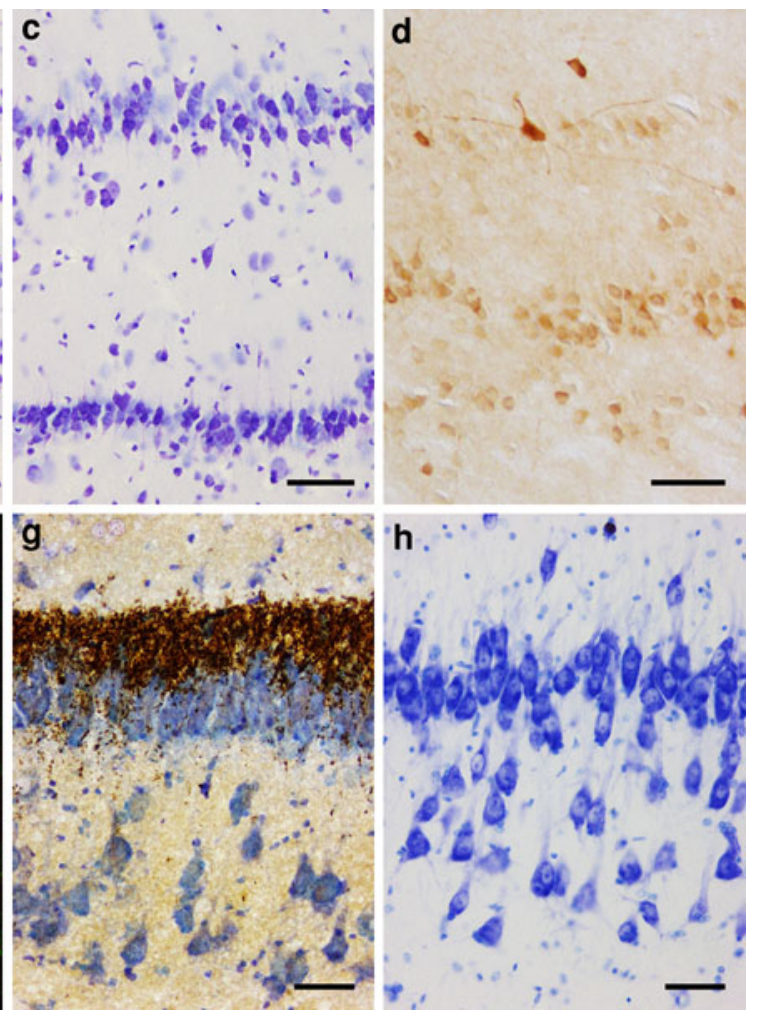

not show appreciable differences in their parvalbumin immunoreactivity. f Zbtb20 (green) in C57B1/6 mouse superficial pyramidal cells and Sox5 (red) in deep pyramidal cells. g Scattered deep pyramidal cells in distal CA3 of the Chincilla do not receive mossy fiber input close to their soma. $\mathbf{h}$ Scattered deep pyramidal cells in distal CA3 of the fox. Scalebars $\mathbf{a} 0.5 \mathrm{~mm}, \mathbf{b}-\mathbf{h} 50 \mu \mathrm{m}$. The original of $\mathbf{f}$ was kindly provided by Prof. Niels A. Jensen (Nielsen et al. 2010, with permission of Oxford University Press) 
A similar segregation of pyramidal cells has been observed in mice homozygous for the scrambler mutation of the Dabl gene (Gonzáles et al. 1997; Ohshima et al. 2001), which presumably acts downstream of the reeler gene in laminar development, and in mice heterozygous for a disruption of the Lisl gene (Hirotsune et al. 1998), which codes for the $\beta$ subunit of platelet-activating factor acetylhydrolase. A layering of CA1 is also seen in doublecortin(Dcx)/Dcx-like kinase mutant mice (Deuel et al. 2006), which lack these microtubule-associated proteins required for normal cortical and hippocampal development. Lamination is more severely disturbed in double heterozygous Dcx/Lis 1 knockout mice, which show a multi-layered distribution of CA1 pyramidal cells (Pramparo et al. 2010). Notably, the ablation of both p35, an activator of cyclindependent kinase 5, and reelin results in a homogenous distribution of cells in stratum oriens and the pyramidal cell layer (Ohshima et al. 2001). While morphological changes extend beyond CA1, the pattern within CA1 at least resembles that seen in microchiropteran bats and primates.

The different migratory capabilities of neurons in knockout mice or mice carrying natural mutations may be caused by cell-intrinsic factors other than the primary mutation, which should affect all pyramidal cells. Alternatively, extrinsic factors, such as spatial barriers set up by ingrowing afferents (Ishida et al. 1994; Deller et al. 1999), may be responsible. Cell-intrinsic factors would per se distinguish the two populations. Extrinsic factors will, in a structure in which the laminar specificity of afferents is the most characteristic feature, distinguish the two populations functionally. Either way, to maintain the concept of homogeneity of the pyramidal cell layer becomes a more complex task. Furthermore, the aggregation of superficial CA1 pyramidal cell depends on their developmental expression of Zbtb20 (Fig. 3f), a member of the BTB/POZ zinc finger family (Mitchelmore et al. 2002), without which CA1 develops a cortex-like structure (Xie et al. 2010). Misexpression of Zbtb20 in extrahippocampal neurons results in the aggregation of cells of the upper layers of adjacent subicular fields in a compact CA1-like superficial layer (Nielsen et al. 2007, 2010). Zbtb20 is co-expressed with Satb2 (Nielsen et al. 2010; Xie et al. 2010), which is also required for the development of superficial neocortical layers (Britanova et al. 2008). Also, Zbtb20 expression is mutually exclusive with the expression of Sox 5 (Fig. 3f), which in the neocortex is necessary for the speciation of deep corticofugal neurons (Lai et al. 2008).

\section{CA3}

Natural mutations of common laboratory species that resolve different sublayers in CA3 as strikingly as in CA1 are not known. Although sublayers are visible in illustrations of
CA3 of scrambler mice (Gonzáles et al. 1997, their figure 3c) it has not been described whether this pattern is consistent. Milder lamination changes are present in BALB/ c, dreher mice, and weaver mice (Vaughn et al. 1977; Nowakowski 1984; Nowakowski and Davis 1985; Sekiguchi et al. 1992, 1995) and appear to affect neurons differentially according to their time of generation (Vaughn et al. 1977).

More recently, a lamination defect has been described in CA3 and, to a lesser extent, in CA1 of mice carrying a targeted mutation in the $D c x$ gene (Corbo et al. 2002; Nosten-Bertrand et al. 2008; Kappeler et al. 2007). In these mice, ectopic CA3 pyramidal cells can be found in both stratum oriens and radiatum and may give short segments of CA3 a bilaminar appearance. A similar phenotype has been observed in knock-out mice deficient in p35 (Ohshima et al. 2005) and Lisl mutant mice (Wang and Baraban 2008). A bilaminar proximal CA3 pyramidal cell layer and ectopic clusters of pyramidal cells in stratum oriens of distal CA3 have be found in Fukutin-knockout mice (Takeda et al. 2003). "Abnormalities" of this type can be found in distal and temporal CA3 segments of the Chincilla, in which pyramidal-like cells form a second cell tier in stratum oriens. Notably, at least the proximal dendrites of these ectopic cells are not targeted by mossy fibers (Fig. 3g). A loosely packed band of cells also characterizes stratum oriens of distal CA3 in the fox (Fig. 3h).

\section{CA1 and CA3}

CA1 lamination defects in Dcx/Dcx-like kinase double mutant mice (Deuel et al. 2006) and in $\alpha-1$ tubulin mutant mice (Keays et al. 2007) extend into CA3 and appear more pronounced than those resulting from mutations in $p 35$ or $D c x$ alone. Knockdown of the actin-binding protein girdin or an inhibition of the interaction of girdin with DisruptedIn-Schizophrenia1 (DISC1) result in appearance of abnormal layers in CA1 and CA3 (Enomoto et al. 2009). While the Fukutin-knockout alone does not affect lamination beyond CA3, it may do so in O-mannosyltransferase 2 knockout mice (POMT2, Hu et al. 2011), in which loose clusters of CA1 pyramidal cell are found beneath a compact superficial layer not dissimilar to the pattern seen in possum or mole rat. Last, a distinct bilaminar pyramidal cell layer in CA1 and CA3 is seen in mice deficient in microtubule-actin crosslinking factor 1a (Goryunov et al. 2010).

\section{Neurochemistry}

At least two substances that are selectively distributed to, in both cases, superficial pyramidal cells have the potential to modulate responses of $\mathrm{CA} 1$ cells to afferent stimulation or to modulate the effect that CA1 efferents may have in their 

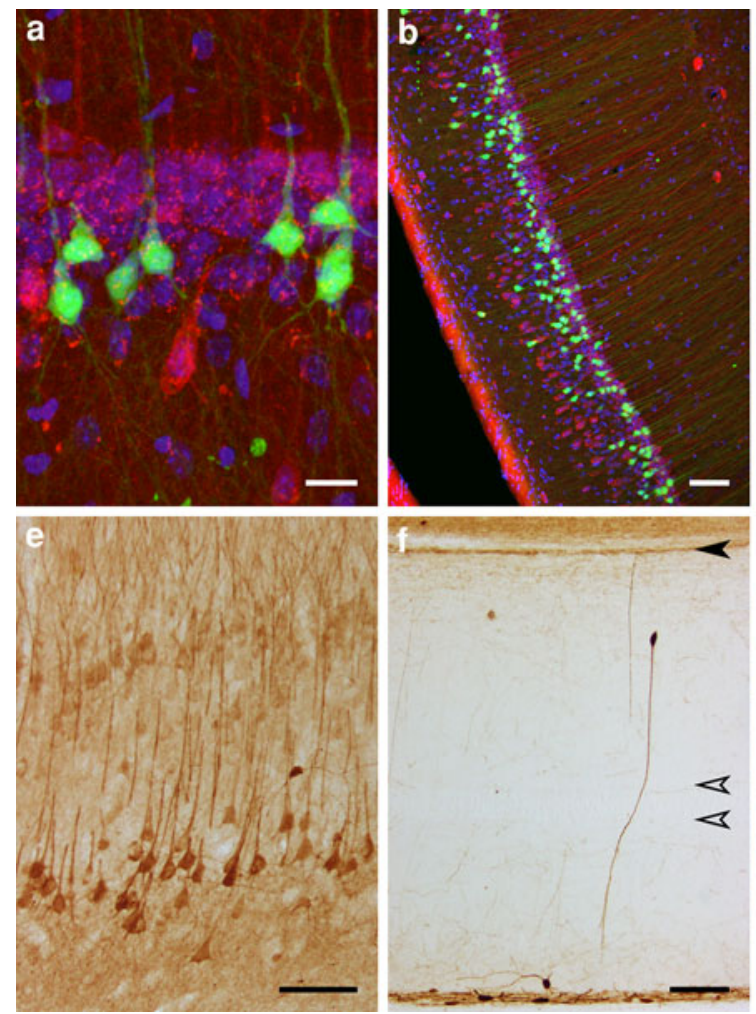

Fig. 4 Calbindin-immunoreactive (CaBP-ir) and green-fluorescent protein expressing pyramidal cells in $\mathbf{a}$ the septal CA1 and $\mathbf{b}$ the distal mid-septotemporal CA1 of thy1-GFP (M line) transgenic mice. c CaBP-ir CA1 pyramidal cells in septal CA1 of Wistar rat. Some of the voids left by unstained deep cells are marked with an asterisk. d Zinc-containing pyramidal cells in mid-septotemporal, mid-proximodistal CA1 of Wistar-Kyoto rat. e CaBP-ir CA1 pyramidal cells in temporal one-half of th fox CA1. Lightly CaBP-ir superficial cells are separated from a tier of strongly CaBP-ir, large deep pyramids by

target areas-calbindin and zinc. They are discussed in some detail below. Efforts have been made to rationally define functional domains along the hippocampal septo-temporal axis. A number of genes have been identified that may define such domains (Fanselow and Dong 2010; Dong et al. 2009; Thompson et al. 2008), and some of them are expressed preferentially in either superficial or deep pyramidal cells of both CA1 (e.g. Nov and Nr3c2 in superficial and Ndst4 and Astn2 in deep septal pyramidal cells) and CA3 (potassium channel subunit, Kcnq5, in superficial and procollagen gene Col6al and suppressor of tumorigenicity 18, St18, in deep mid-septotemporal pyramidal cells). Their laminar distributions appear to coincide with those of calbindin and zinc.

Calbindin. The distribution of calbindin immunoreactive (CaBP-ir) pyramidal cells in CA1 of the rat hippocampus probably represents the earliest neurochemical evidence for a radial subdivision of the layer. Throughout most of the transverse extent of the layer, CaBP-ir pyramidal cells are located in the cell-dense superficial part, while deeper pyramidal cells do not contain this protein (Baimbridge and

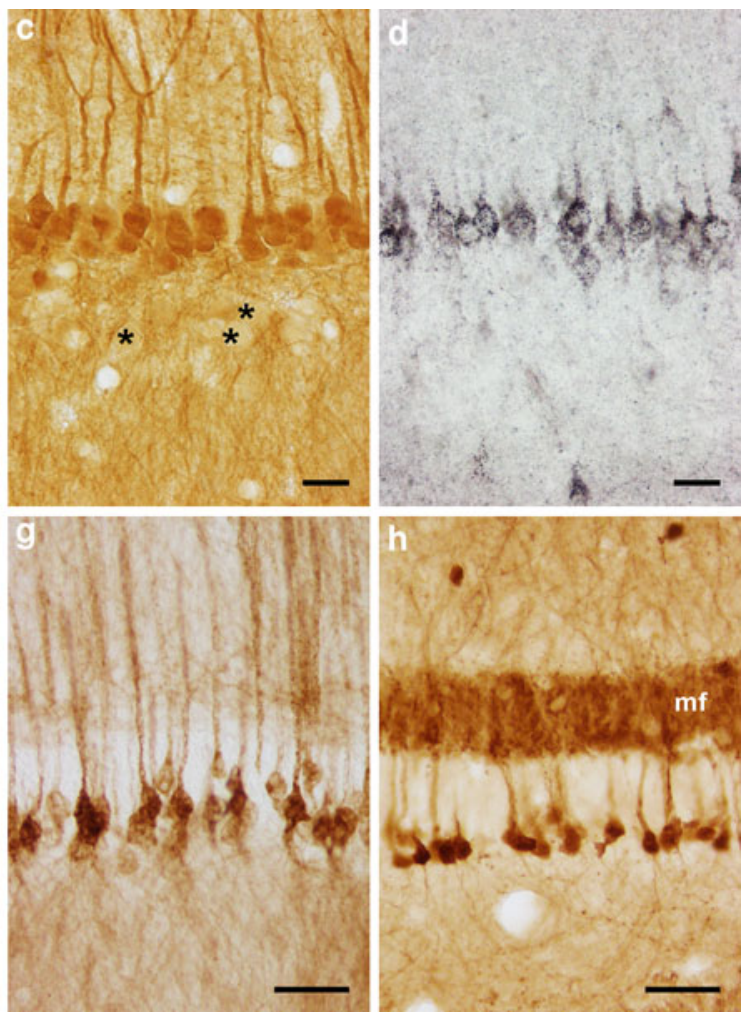

virtually unstained cells. $\mathbf{f}$ Cells in the septal three-quarters of the elephant shrew CA1 pyramidal cell layer (delimited by open arrows) are completely unstained. The filled arrow marks the boundary between stratum radiatum and stratum lacunosum-moleculare. g CaBP-ir deep CA1 pyramidal cells in the temporal CA1 of the elephant shrew. $\mathbf{h}$ CaBP-ir deep CA3 pyramidal cells in naked mole rats, $m f$ : CaBP-ir mossy fibers. Scalebars $\mathbf{a}, \mathbf{c}$ and $\mathbf{d} 20 \mu \mathrm{m} ; \mathbf{b}, \mathbf{g}$ and h $50 \mu \mathrm{m}$; e and f $100 \mu \mathrm{m}$

Miller 1982; Rami et al. 1987b; Sloviter 1989; Celio 1990). In the septal hippocampus, CaBP-ir pyramidal cells form a superficial mono- or bilayer above unstained deeper cells (Fig. 4c; also compare with Fig. 21, m). Only at the proximal limit of CA1, where CaBP-ir becomes weak superficially, CaBP-ir appears in some of the deepest pyramidal cells. The deepest cells are also stained distally, in the vicinity of the subiculum. Baimbridge et al. (1991) have shown that there was virtually no overlap in the labeling of CaBP-negative and CaBP-ir pyramidal cells when animals were injected with ${ }^{3} \mathrm{H}$-thymidine on $\mathrm{E} 16$ and E18, respectively. Notably, calbindin expression is apparently controlled by Zbtb20 - being down-regulated in cells in which the expression of Zbtb20 has been blocked and appearing in deep pyramidal cells as the expression of Zbtb20 is induced in these cells (Nielsen et al. 2010). Despite their change in location, pyramidal cells in CA1 of reeler mice retain their identities with regard to calbindin expression, which is strongest in the deep sublayer but weak or absent in superficial cells (Fig. 3d). 
The distribution of calbindin in the primate hippocampus, taking into account differences in histoarchitecture, corresponds to the pattern observed in the rat (Seress et al. 1991). The number of CaBP-ir CA1 pyramidal cells and the intensity of the reaction observed in different primate species is, however, variable. In African green monkeys (Chlorocebus aethiops), only a few, weakly reacting cells are seen, which show a prevalence for the upper half of the pyramidal cell layer (Leranth and Ribak 1991). In Rhesus monkeys (Macaca mulatta) many CA1 pyramidal cells are immunoreactive (Seress et al. 1991). In this species, a preference for a specific (superficial) location within the pyramidal cell layer is only shown by strongly CaBP-ir cells (Seress et al. 1991, their Figure 2). In the baboon (Papio papio), virtually all CA1 pyramidal cells have been reported to contain calbindin (Sloviter et al. 1991). Calbindin also marks a subpopulation of human CA1 pyramidal cells (Seress et al. 1992, 1993), which are distributed similarly to those in other primates.

Possibly extending the sparse presence of very deep CaBP-ir pyramidal cells in mice, a distinct third band of CaBP-ir pyramidal cells is present in dogs at the deep border of the cell layer (Hof et al. 1996) in addition to the superficial tier. We observed a similar pattern in the fox, in which the number of deep CaBP-ir pyramidal cells increased towards the temporal pole of the hippocampus while immunoreactivity in superficial cells gradually decreased (Fig. 4e).

Of those species in which there are no appreciable radial differences in cell-density in the CA1 pyramidal cell layer, data on the distribution of CaBP-ir is only available for the guinea pig and rabbit (Rami et al. 1987b; de Jong et al. 1996). $\mathrm{CaBP}$-ir pyramidal cells were not reported in these species. $\mathrm{CaBP}$-ir pyramidal cells are also absent from much of CA1 of elephant shrews (Fig. 4f). However, a change is seen in approximately the temporal one quarter of CA1, in which CaBP-negative superficial pyramidal cells are supplemented by a band of strongly CaBP-ir deep pyramids (Fig. 4g).

Interestingly, green fluorescent protein (GFP) in thy1GFP (M line) transgenic mice is expressed in a calbindinnegative subset of CA1 pyramidal cells both in septal (Fig. 4a) and temporal (Fig. 4b) CA1. Although the reason for this selective expression is not clear, the possibilities that have been raised suggest a relation between the labeled cells in terms of either normal thy1 expression or a differential cell type- or layer-specific recognition by transcription factors at the site of transgene integration (Feng et al. 2000) and imply a functional differentiation between expressing and non-expressing cells.

Zinc. Zinc, located in the synaptic vesicles of a subset of telencephalic boutons, was identified as the endogenous substrate of Timm's sulphide silver methods, which has frequently been used to illustrate hippocampal layers. Like CaBP-ir cells, zinc-containing neurons exhibit a striking preference for sublayers along the radial axis of the pyramidal cell layer in the rat and mouse (Slomianka and Geneser 1991, 1997; Slomianka 1992). They form a densely packed superficial band within the pyramidal cell layer of CA1 throughout the septotemporal extent of the hippocampus in both species (rat: Figs $4 \mathrm{c}$ and $5 \mathrm{a}$ ). Zinc-containing neurons rendered visible in macaque monkey CA1 by retrograde selenite tracing from the inferotemporal cortex are also located in the superficial part of the pyramidal cell layer (Ichinohe and Rockland 2005). The localization of zinc-containing cells in CA1 suggests a colocalization of calbindin and zinc in these cells. CaBP-ir CA1 pyramidal cells were indeed found to be zinc-containing neurons and vice versa (compare Fig. $4 \mathrm{c}$ and $\mathrm{d}$, described in detail in Slomianka et al. 1997). Also, the developmental expression of calbindin-immunoreactivity and the ability to label CA1 pyramidal cells (or dentate granule cells) for zinc appear to coincide temporally (Rami et al. 1987a; Baimbridge 1992; Slomianka and Geneser 1997), which may indicate that the specific cellular properties that depend on the presence of calbindin and zinc become functionally important within the same period of postnatal development.

In CA3 of the rat, zinc-containing neurons are scattered along the route of migration of lately formed pyramidal cells, deep to a compact layer of superficial CA3 pyramids (Fig. 5b, c). Their distribution is somewhat more extensive in CA3 of mice, comprising a larger portion of lately formed CA3 pyramids (Slomianka and Geneser 1997). Calbindin is not found in CA3 pyramidal cells of any commonly used laboratory species or in those of the majority of species we have examined. However, in naked mole rats (Heterocephalus glaber) a striking band of strongly calbindin-immunoreactive pyramidal cells is found at the deep limit of the CA3 pyramidal cell layer (Fig. 4h).

Although the localization of calbindin shows bewildering variations, it remains, when expressed, a marker with laminar specificity. Phylogenetic variability and laminar specificity also characterize this protein in the neocortex (Hof et al. 1999). Possible physiological correlates of differences in the expression of calbindin and zinc are discussed below.

\section{Connectivity}

\section{Efferent connections}

The differential expression of Satb2 and Sox 5 in CA1 pyramidal cells, which specify efferent connectivity by their interactions with other transcription factors in the neocortex (Britanova et al. 2008; Leone et al. 2008), implies differences in the connectivity of deep and 

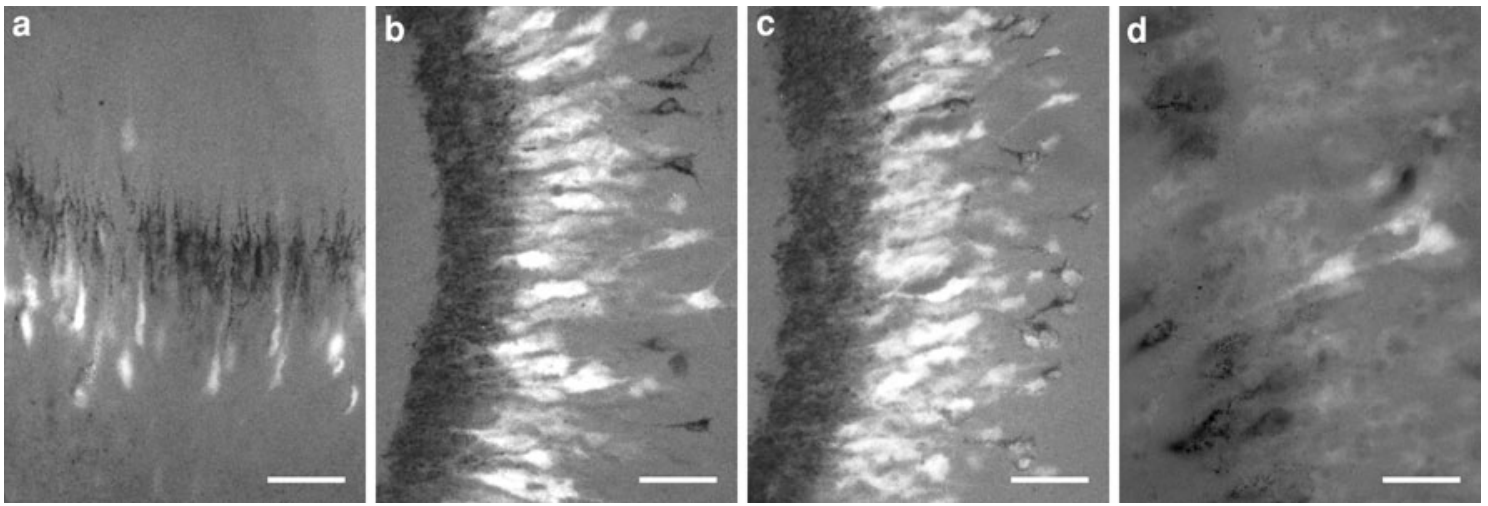

Fig. 5 Mid-septotemporal hippocampus of Wistar Kyoto rats, stained for zinc-containing neurons and fluorescence of the retrograde tracer fluorogold. a In proximal CA1, predominantly deep zinc-negative pyramids label after an injection into the ipsilateral lateral septum. b After a contralateral fluorogold injection into the lateral septum, deep zinc-containing CA3 pyramids are not labeled, whereas c deep

superficial pyramidal cells. A number of retrograde tracing studies in rodents and primates have indeed shown a preference of labeled pyramidal cells to be located either deep or superficially in the cell layer. These include the hippocampo-septal projection (Chronister and DeFrance 1979; see also below), projections from deep CA1 pyramidal cells to the nucleus accumbens (McGeorge and Faull 1989), medial prefrontal (Barbas and Blatt 1995; Insausti and Muñoz 2001; Roberts et al. 2007) and orbitofrontal cortices (Cavada et al. 2000), and projections from superficial CA1 pyramidal cells to the medial temporal cortex (Yukie 2000; Insausti and Muñoz 2001). In a study of hippocampo-septal connections (Sørensen et al. 1993) we found that projections to the septum originate from zinccontaining as well as zinc-negative pyramidal cells of much of CA1 while septal projections originate primarily from zinc-negative deep pyramidal cells in extreme proximal CA1 (Fig. 5a), a part of the layer that is likely to correspond to CA2. More strikingly, zinc-containing deeply situated cells in CA3 project almost exclusively to the ipsilateral septum while zinc-negative superficial pyramidal cells have strong bilateral septal connections (Fig. 5b, c). In a study of the zinc-containing afferent circuitry of the striatum (Sørensen et al. 1995) we observed that CA1 pyramidal cells projecting to the ventral striatum/nucleus accumbens are found among the zinc-negative deep pyramidal cells (Fig. 5d).

Based on multiple injections of different tracers, Swanson et al. (1980) proposed that CA3 pyramidal cells form a population of neurons, which have virtually identical efferent projections. Their sections were obtained from within the septal one-third of CA3, whereas zinccontaining cells are mainly located within the temporal half of CA3. Even at temporal levels, the estimates made at

zinc-containing CA3 pyramids are labeled after an ipsilateral fluorogold injection into the lateral septum. d Only deep zincnegative pyramidal cells in distal CA1 are retrogradely labeled after an ipsilateral fluorogold injection into the ventral striatum. Scalebars a-c $50 \mu \mathrm{m} ; \mathbf{d} 25 \mu \mathrm{m}$

septal levels (more than 50\% multiple labeling, Swanson et al. 1980) provide sufficient leeway from "virtual identity" to accommodate different septal connections of zinccontaining and zinc-negative pyramidal cells.

\section{Afferent connections}

Defining differences in the afferent connectivity of deep and superficial pyramidal cells would require an identification of individual cells postsynaptic to afferents that have been visualized either by tract tracing procedures or immunocytochemistry (e.g. Kajiwara et al. 2008). This task is not easily accomplished, and data on afferent connections specific to deep or superficial pyramidal cells are scarcer than on efferent connections. Early evidence concerns local inhibitory afferents as described by Lorente de No (1934), who states “... the second reason [to distinguish both types of pyramids] is that the superficial and deep pyramids have a different relation to the pyramidal, horizontal and polygonal basket cells. The superficial pyramids are in contact with the end arborizations of pyramidal, horizontal and polygonal cells. The deep pyramids are chiefly in contact with the polygonal basket cells, and the deepest have almost no contact with the basket plexus." Unfortunately, this observation is not being commented on further in the extensive literature on inhibitory hippocampal neurons and their targets within CA1 and CA3 (reviewed in Freund and Buzsáki 1996; Klausberger and Somogyi 2008). With regard to interneurons characterized by the presence of parvalbumin, the innervation of the two pyramidal cell layers in reeler mice does not show gross differences (Fig. 3e, Ishida et al. 1994). That inhibitory mechanisms of deep and superficial pyramidal cells may differ is supported by the selective 
vulnerability of superficial cells to focal injections of low doses of $\gamma$-acetylenic GABA (Goodman 1998), an indirect excitotoxin, which attenuates the formation of kynurenate and GABA and which produces selective cell death also in other parts of the hippocampal formation (Wu and Schw$\operatorname{arcz} 1998)$.

Additional evidence for distinct afferent connections of superficial and deep CA1 pyramidal cells is provided by Bannister and Larkman (1995), who showed that, in the rat, deep pyramidal cells extend less of their dendritic tree into stratum radiatum than superficial pyramidal cells. A significantly higher apical dendritic aborization of superficial pyramidal cells in comparison with cells located at deeper levels was also observed in macaque monkeys (Altemus et al. 2005). In the rat, relative position alone does not explain this distribution pattern as deep pyramidal cell are able to extend dendrites into the stratum moleculare to a similar extent as superficial pyramidal cells (Bannister and Larkman 1995). Differences in dendritic arborizations suggest differences in afferent connectivity because intrinsic and extrinsic hippocampal afferents show differences in their predilection to terminate either in the stratum oriens or the stratum radiatum (van Groen and Wyss 1988). The precise patterns of distribution also relate to septo-temporal and proximo-distal relations between the sources of intrinsic afferents in CA3 and their targets in CA1 (Ishizuka et al. 1990). While it is unlikely that either deep or superficial cells are exclusive targets of parts of the intrinsic afferent circuitry, quantitative differences in the sourcing of afferents from specific septotemporal and proximodistal hippocampal levels should exist. Experimental support for this idea comes from two studies of intrinsic afferents of the reeler mouse CA1 and the morphology of the pyramidal cells located in the two cell tiers. Tracings of commissural fibers by Borrell et al. (1999) show a preference for these fibers to terminate above the superficial tier of cells. Only few dendrites of deep pyramidal cells extend into this layer (Deller et al. 1999), and superficial pyramids should be the primary targets of these fibers.

In the Guaira spiny rat, which resembles the Parma wallaby and fox in the histoarchitecture of the pyramidal cell layer, the dendritic length of pyramidal cells located within the stratum oriens exceed that of more superficial pyramidal cells by a factor two (Scorza et al. 2011), suggesting a phylogenetic regulation of not only the sourcing but also the number of inputs of superficial and deep pyramids.

Differences in the extent of the dendritic trees of rat superficial and deep pyramidal cells have also been described for CA3 (Fitch et al. 1989), however, with a higher arborization of the dendrites of superficial pyramidal cells both superficial and deep to the pyramidal cell layer.
Although not directly concerned with the radial position of pyramidal cells, the findings of Deguchi et al. (2011) in mice sparsely expressing GFP also provide evidence for different intrinsic connections of superficial and deep pyramidal cells. The authors show that pyramidal cell generated during a particular time window in CA3 preferentially connect with a developmentally matched set of CA1 pyramids. In addition, the interconnected cell populations are characterized by distinct gene expression patterns. The findings were thought to represent functional streams, which actually begin already in the dentate gyrus. As the time of pyramidal cells origin also determines their radial position, superficial and deep cells should belong to different streams, and it is tempting to think that the histoarchitectural differentiation of the pyramidal cell layer is a structural reflection of such functional streams.

\section{Physiology}

Normal physiology

Unless specified otherwise, data mentioned in the following were obtained in laboratory rats or mice. In vitro, calbindin expression has been found to abolish post-tetanic potentiation in hippocampal neurons (Chard et al. 1995) and intracellular calcium antagonizes the NMDA-type glutamate receptors (Koh and Choi 1994). Considering the differences in calbindin content and the differential distribution of deep and superficial pyramidal dendrites (Bannister and Larkman 1995), one may expect that the stimulation of basal dendrites would be more efficient in eliciting NMDA receptor-dependent LTP than the stimulation of apical dendrites. A number of reports indicate that this is indeed the case (Capocchi et al. 1992; Kaibara and Leung 1993; Leung and Shen 1995; Arai et al. 1994). NMDA receptor-independent apical and basal LTP exhibit few if any differences in naive hippocampal slices but are instead differentially affected by calcium channel blockers and tyrosine kinase inhibitors (Cavus and Teyler 1998).

A differential responsiveness of cells may also be reflected in the preferential expression of the immediate early genes $c$-Fos and JunB in deep pyramidal cells following context dependent memory retrieval (Strekalova et al. 2003, their Fig. 2). Also, contextual fear conditioning and extinction upregulate c-Fos and extracellular signal regulated kinase (Erk) in distinct populations of CA1 pyramidal cells (Tronson et al. 2009) with seemingly different radial distributions. Two classes of pyramidal cells could also be defined based on their gamma firing phases during theta oscillations (Senior et al. 2008), and it was 
suggested that these classes may correspond to deep and superficial pyramidal cells. Similarly, late depolarizing postsynaptic potentials in response to commissural or Schaffer collateral stimulation were observed in only one (L-type) of two classes of septal CA1 pyramidal cells (Fan et al. 2005) that have dendritic distributions similar to the superficial pyramids described by Bannister and Larkman (1995).

In addition to the regulation of the response characteristics of cells to afferent stimulation, calbindin may also influence transmission presynaptically by impeding pairedpulse facilitation until $\mathrm{Ca}^{2+}$-buffer saturation (Blatow et al. 2003; Dumas et al. 2004). This may distinguish the way in which deep and superficial CA1 pyramidal cells can affect their targets. This is also true for zinc, the second neurochemical that distinguishes superficial and deep pyramidal cells. Zinc affects a vast array of ligand- and voltage-gated ion channels (Frederickson et al. 2005). Prominent among zinc effects is a potent modulation of both NMDA and nonNMDA glutamate receptor function (Paoletti et al. 2009) through interactions with subunit specific zinc-binding sites (Paoletti et al. 2000; Rachline et al. 2005). How antagonistic effects on NMDA receptors and agonistic effects on AMPA and kainate receptors translate into models of hippocampal function will depend on the functional connectivity of the zinc-containing deep CA3 and superficial CA1 pyramidal cells.

A radial difference in the physiology of guinea pig CA3 pyramidal cells is a preference for burst-type firing cells to be located in the deep part of the cell layer (Bilkey and Schwartzkroin 1990). Cells with different firing characteristics may correspond to those distinguished morphologically in rats by Fitch et al. (1989). An earlier study (Masukawa et al. 1982) reported a preferential location of these cells in proximal CA3. Overlapping neurogenetic gradients distributing different pyramidal cells types along both transverse and radial gradients may explain this discrepancy.

A study in the Guaira spiny rat is the only one in which the physiological properties of deep and superficial pyramidal cells have been systematically investigated in a CA1 showing a dense superficial layer above a zone of loosely distributed pyramids that spans much of the stratum oriens (Scorza et al. 2011). Deep pyramidal cells located in the stratum oriens showed distinctly higher membrane capacitance, latency to fire at threshold and rheobase, but a lower input resistance and depolarizing sag than superficial pyramidal cells.

Pathology and pathophysiology

Tabuchi et al. (1995) observed degenerative changes preferentially in deep CA1 pyramidal cells after short periods of ischemia in Japanese macaques. A preferential degeneration of deep CA1 pyramidal cells was also observed during early postnatal development in rabbits as a consequence of pilocarpine-induced seizures (Towfighi et al. 2004). A higher incidence of depolarizing responses to anoxia has been found in rat deep CA1 pyramidal cells when compared with superficial cells (Morris et al. 1995). Differential effects of ischemia on CA1 pyramidal cells of the L- and non-L-types (Fan et al. 2005) have also been observed (Ruan et al. 2007).

Some of these observations would be compatible with a neuroprotective role of calbindin (Scharfman and Schwartzkroin 1989; Mattson et al. 1991; Guo et al. 1998). However, superficial pyramidal cells in rabbits do not contain calbindin, and CA1 pyramidal cells of calbindinknockout mice were more resistant to overt ischemia than their counterparts in wild-type mice (Klapstein et al. 1998). That additional factors are likely to be involved is suggested by (1) the differential response of deep and superficial rabbit CA1 cells, neither of which contain calbindin and (2) the survival of both superficial and deep cells in the calbindin-knockout mice, in which only superficial cells should be immediately affected.

\section{One, two or more?}

Based on this short review we feel that it is very difficult to maintain the concept of pyramidal cell homogeneity along the radial axis of the cell layer. Rather it seems that in many species distinct deep and superficial populations of pyramidal cells can be identified, which differ in neurochemistry, connectivity, and their reactions to selective pressures exerted during the phylogeny of particular species. Examples of features distinguishing superficial and deep CA1 pyramidal cells are summarized in Fig. 6. A similar division of CA3 pyramidal cells may be superimposed on stronger proximo-distal gradients.

How many layers should we then recognize? Gene expression studies, zinc and calbindin suggest that even the compact pyramidal cell layer of the septal hippocampus can be divided into two sublayers. Further temporally and in distal CA1, they appear to be supplemented by a third, deep sublayer, which again can be characterized by the presence of calbindin and a distinct gene expression pattern. In some respects these layers reflect principles of neocortical organization with small superficial cells maintaining connections to nearby cortical areas, while deep cells are mainly responsible for long-distance intercortical and subcortical telencephalic communication. Analogizing hippocampal and neocortical layers came easy to Schaffer (1892), who could state that the laminar organization of the CA fields completely reflected that of "typical cortex", and 


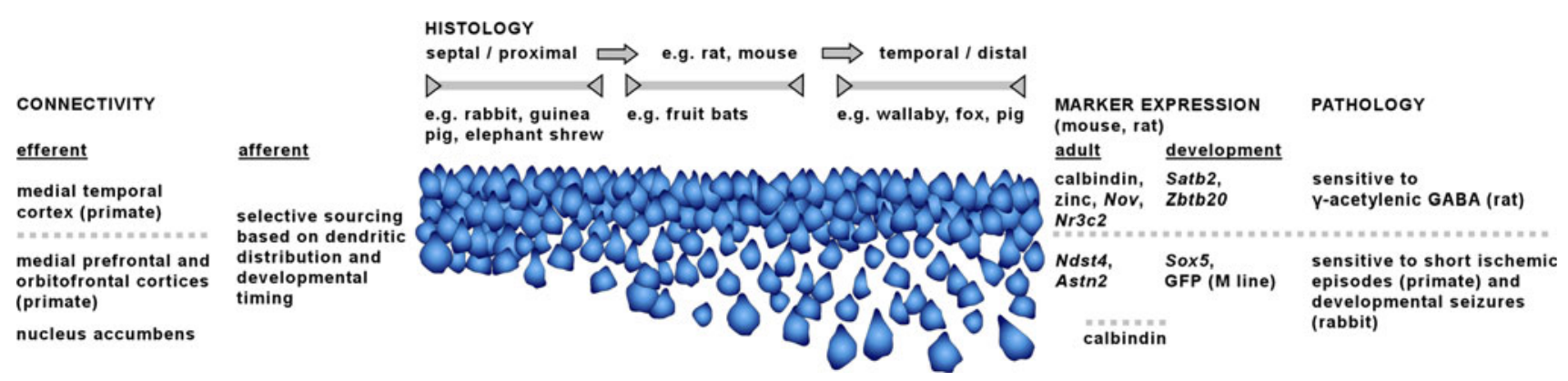

Fig. 6 Examples of particularly interesting histoarchitectural, connectional, neurochemical and pathological findings that distinguish superficial and deep pyramidal cells of CA1. The cell layer has been drawn to resemble the different appearances of the layer along both

similar views were still expressed by Rose (1926) and Abbie (1938). Only with Krieg (1946) does "the subiculum carr[y] the reduction of layers to its logical conclusiononly one layer remains", which continues compacted into the hippocampus. The number of layers present is actually not of primary importance-neither is their degree of homology to layers in other cortical areas. At issue is an acknowledgement of layering, which in time may generate the data necessary to decide on their number and relation to the cortex.

\section{Distinct output streams or parts of translaminar functional units?}

Deep and superficial pyramidal cells may merely represent distinct output streams of the hippocampus. However, beyond differences in cellular phenotypes, cortical lamination implies functional interactions between layers. Are there interactions between pyramidal cells in the sublayers, and, if so, how are they mediated? Current evidence suggests that pyramidal-pyramidal cell connections within CA1 are sparse as compared to neocortical areas or CA3 (Deuchars and Thomson 1996). Tract tracing studies also suggest weak associational pathways in CA1 (Amaral et al. 1991; Swanson et al. 1978). After some developmental pruning (Aniksztejn et al. 2001), they are limited to stratum oriens of the adult rat (Amaral et al. 1991; Tamamaki et al. 1987). A restricted distribution along the longitudinal and transverse axis of CA1 (Swanson et al. 1978), with axon branches of a CA1 pyramidal cell most prominent among its basal dendrites (Tamamaki et al. 1987), suggests primarily local, patch-like associational interactions, which may help create local cellular ensembles of the type described by, e.g., Eichenbaum et al. (1989) or Nakamura et al. (2010).

An alternate way of local interactions may be the local dendritic or somatic electrotonic coupling of pyramidal the septotemporal and proximodistal axis in mouse and rat. In other species much of CA1 is dominated by a histoarchitectural phenotype that encompasses only a narrow segment of the variations seen in rat and mouse

cells (Andrew et al. 1982; Núñez et al. 1990; Baimbridge et al. 1991; Mercer et al. 2006), which has been a matter of discussion ever since its first description (Knowles et al. 1982; Bennett and Pereda 2006). In a more recent incarnation, evidence for axo-axonal coupling of cells has also been presented (Schmitz et al. 2001). Of note are evidence for an activity-dependent incidence of coupling (PerezVelazquez et al. 1994; Church and Baimbridge 1991; Perez Velazquez and Carlen 2000) and the participation of both superficial and deep cells in coupled groups, which did lead Baimbridge et al. (1991) to suggest that they represent a functional unit. An activity/state-dependent coupling of distinct output streams seems possible. Proximity is a key determinant in the likelihood of two cells to be connected, and the degree to which pyramidal cells condense into a compact layer may regulate this type of interaction phylogenetically.

\section{Where to go next}

An immediate step forward would be to go back to existing data. During our review, we have occasionally seen illustrations that suggest layers within CA1 or CA3, but that without support in writing remained inconclusive. Since expectation may tint perception, reviewing existing data for evidence of sublayers may be worthwhile. The array of natural mutations and transgenic mice that exhibit lamination "defects" may facilitate the definition of the anatomical and physiological phenotypes of deep and superficial pyramidal cells. The selective expression of GFP in a subset of pyramidal cells that belongs to a neurochemically defined group in thy1-GFP (M line) or in other sparsely GFP expressing mouse lines offer direct access to the characterization of their physiological and connective properties in comparison with non-expressing cells using the approaches outline by Kajiwara et al. (2008) and used so effectively by Deguchi et al. (2011). The 
selective ablation of superficial pyramidal cells with $\gamma$ acetylenic GABA may help to define the functional importance of the two cell populations.

The concept of a radial subdivision of the hippocampal pyramidal cell layer is rarely consciously considered in anatomical studies of the hippocampus, and it is, to our knowledge, not part of any computational model of hippocampal function. The understanding of neocortical function depends critically upon an understanding of laminar cortical organization with specific afferents terminating in specific layers, information being routed in specific ways between layers, efferent pathways originating in specific layers, etc. An appreciation of a radial laminar organization within the classically identified subfields of the hippocampus may contribute to our understanding of hippocampal function(s) to a similar extent.

Acknowledgments Investigations of some of the species were made possible by funding through the Swiss South African Joint Research Programme (SSAJRP) to IA. We greatly appreciate the help of Dr. Urs Ziegler (Center for Microscopy and Image Analysis, University of Zürich) in preparing figures $4 \mathrm{a}$ and $\mathrm{b}$.

Open Access This article is distributed under the terms of the Creative Commons Attribution Noncommercial License which permits any noncommercial use, distribution, and reproduction in any medium, provided the original author(s) and source are credited.

\section{References}

Abbie AA (1938) The relations of the fascia dentata, hippocampus and neocortex, and the nature of the subiculum. J Comp Neurol 68:307-333. doi:10.1002/cne.900680303

Altemus KL, Lavenex P, Ishizuka N, Amaral DG (2005) Morphological characteristics and electrophysiological properties of CA1 pyramidal neurons in macaque monkeys. Neuroscience 136:741-756. doi:10.1016/j.neuroscience.2005.07.001

Altman J, Bayer SA (1990) Prolonged sojourn of developing pyramidal cells in the intermediate zone of the hippocampus and their settling in the stratum pyramidale. J Comp Neurol 301:343-364. doi:10.1002/cne.903010303

Amaral DG (1993) Emerging principles of intrinsic hippocampal organization. Curr Opin Neurobiol 3:225-229

Amaral DG, Dolorfo C, Alvarez-Royo P (1991) Organization of CA1 projections to the subiculum: a PHA-L analysis in the rat. Hippocampus 1:415-436. doi:10.1002/hipo.450010410

Andrew RD, Taylor CP, Snow RW, Dudek FE (1982) Coupling in rat hippocampal slices: dye transfer between CA1 pyramidal cells. Brain Res Bull 8:211-222. doi:10.1016/0361-9230(82)90048-X

Angevine JB Jr (1965) Time of neuron origin in the hippocampal region. An autoradiographic study in the mouse. Exp Neurol 11(Suppl 1):1-70. doi:10.1016/0014-4886(65)90121-4

Aniksztejn L, Demarque M, Morozov Y, Ben-Ari Y, Represa A (2001) Recurrent CA1 collateral axons in developing rat hippocampus. Brain Res 913:195-200. doi:10.1016/S00068993(01)02817-7

Arai A, Black J, Lynch G (1994) Origins of the variations in longterm potentiation between synapses in the basal versus apical dendrites of hippocampal neurons. Hippocampus 4:1-10. doi: 10.1002/hipo.450040103

Baimbridge KG (1992) Calcium-binding proteins in the dentate gyrus. In: Ribak CE, Gall CM, Mody I (eds) The dentate gyrus and its role in seizures, Supplement 7. Epilepsy research. Elsevier, Amsterdam, pp 211-220

Baimbridge KG, Miller JJ (1982) Immunocytochemical localization of calcium-binding protein in the cerebellum, hippocampal formation and olfactory bulb of the rat. Brain Res 245:223-229. doi:10.1016/0006-8993(82)90804-6

Baimbridge KG, Peet MJ, McLennan H, Church J (1991) Bursting response to current-evoked depolarization in rat CA1 pyramidal neurons is correlated with lucifer yellow dye coupling but not with the presence of calbindin- $\mathrm{D}_{28 \mathrm{k}}$. Synapse 7:269-277. doi: 10.1002/syn.890070404

Bannister NJ, Larkman AU (1995) Dendritic morphology of CA1 pyramidal neurones from rat hippocampus: I. Branching patterns. J Comp Neurol 360:150-160. doi:10.1002/cne.903600111

Barbas H, Blatt GJ (1995) Topographically specific hippocampal projections target functionally distinct prefrontal areas in the rhesus monkey. Hippocampus 5:511-533. doi:10.1002/hipo. 450050604

Baron G, Stephan H, Frahm HD (1996) Comparative neurobiology in Chiroptera. Morphology, brainstructures, tables and atlases, vol 1. Birkhäuser Verlag, Basel

Bayer SA (1980) Development of the hippocampal region in the rat I. Neurogenesis examined with ${ }^{3} \mathrm{H}$-thymidine autoradiography. J Comp Neurol 190:87-114. doi:10.1002/cne.901900107

Bennett MVL, Pereda A (2006) Pyramid power: principal cells of the hippocampus unite!. Brain Cell Biol 25:5-11. doi:10.1007/ s11068-006-9004-x

Bilkey DK, Schwartzkroin PA (1990) Variation in electrophysiology and morphology of hippocampal CA3 pyramidal cells. Brain Res 514:77-83. doi:10.1016/0006-8993(90)90437-G

Blackstad TW (1956) Commissural connections of the hippocampal region in the rat, with special reference to their mode of termination. J Comp Neurol 105:417-537. doi:10.1002/cne. 901050305

Blatow M, Caputi A, Burnashev N, Monyer H, Rozov A (2003) $\mathrm{Ca}^{2+}$ buffer saturation underlies paired pulse facilitation in calbindinD28k-containing terminals. Neuron 38:79-88. doi:10.1016/ S0896-6273(03)00196-X

Blatt GJ, Rosene DL (1998) Organization of direct hippocampal efferent projections to the cerebral cortex of rhesus monkey: projections from $\mathrm{CA} 1$, prosubiculum, and subiculum to the temporal lobe. J Comp Neurol 392:92-114. doi:10.1002/ (SICI) 1096-9861(19980302)392:1<92:AID-CNE7>3.0.CO;2-K

Borrell V, Ruiz M, del Rio JA, Soriano E (1999) Development of commissural connections in the hippocampus of reeler mice: evidence of an inhibitory influence of Cajal-Retzius cells. Exp Neurol 156:268-282. doi:10.1006/exnr.1999.7022

Braak H (1974) On the structure of the human archicortex I. The cornu ammonis. A Golgi and pigmentarchitectonic study. Cell Tissue Res 152:349-383. doi:10.1007/BF00223955

Britanova O, de Juan Romero C, Cheung A, Kwan KY, Schwark M, Gyorgy A, Vogel T, Akopov S, Mitkovski M, Agoston D, Sestan N, Molnár Z, Tarabykin V (2008) Satb2 is a postmitotic determinant for upper-layer neuron specification in the neocortex. Neuron 57:378-392. doi:10.1016/j.neuron.2007.12.028

Buhl EH, Dann JF (1991) Cytoarchitecture, neuronal composition, and entorhinal afferents of the flying fox hippocampus. Hippocampus 1:131-152. doi:10.1002/hipo.450010203

Capocchi G, Zampolini M, Larson J (1992) Theta burst stimulation is optimal for induction of LTP at both apical and basal dendritic synapses on hippocampal CA1 neurons. Brain Res 591:332-336. doi:10.1016/0006-8993(92)91715-Q 
Cavada C, Compañy T, Tejedor J, Cruz-Rizzolo RJ, Reinoso-Suárez F (2000) The anatomical connections of the macaque monkey orbitofrontal cortex. A review. Cerebral Cortex 10:220-242. doi: 10.1093/cercor/10.3.220

Caviness VS Jr (1973) Time of neuron origin in the hippocampus and dentate gyrus of normal and reeler mutant mice: an autoradiographic analysis. J Comp Neurol 151:113-120. doi:10.1002/ cne. 901510203

Cavus I, Teyler TJ (1998) NMDA receptor-independent LTP in basal versus apical dendrites of CA1 pyramidal cells in rat hippocampal slice. Hippocampus 8:373-379. doi:10.1002/(SICI)10981063(1998)8:4<373:AID-HIPO5>3.0.CO;2-I

Celio MR (1990) Calbindin D-28k and parvalbumin in the rat nervous system. Neuroscience 35:375-475. doi:10.1016/0306-4522(90) 90091-H

Chard PS, Jordan J, Marcuccilli CJ, Miller RJ, Leiden JM, Roos RP, Ghadge GD (1995) Regulation of excitatory transmission at hippocampal synapses by calbindin $\mathrm{D}_{28 \mathrm{k}}$. Proc Natl Acad Sci USA 92:5144-5148

Chronister RB, DeFrance JF (1979) Organization of projection neurons of the hippocampus. Exp Neurol 66:509-523. doi: 10.1016/0014-4886(79)90198-5

Church J, Baimbridge KG (1991) Exposure to high-pH medium increases the incidence and extent of dye-coupling between rat hippocampal CA1 pyramidal neurons in vitro. J Neurosci 11:3289-3295

Corbo JC, Deuel TA, Long JM, LaPorte P, Tsai E, Wynshaw-Boris A, Walsh CA (2002) Doublecortin is required in mice for lamination of the hippocampus but not the neocortex. J Neurosci 22:7548-7557

Coulin C, Drakew A, Frotscher M, Deller T (2001) Stereological estimates of total neuron numbers in the hippocampus of adult reeler mutant mice: evidence for an increased survival of CajalRetzius cells. J Comp Neurol 439:19-31. doi:10.1002/cne.1332

de Jong GI, Naber PA, van der Zee EA, Thompson LT, Disterhoft JF, Luiten PGM (1996) Age-related loss of calcium binding proteins in rabbit hippocampus. Neurobiol Aging 17:459-465. doi: 10.1016/0197-4580(96)00030-9

Deguchi Y, Donato F, Galimberti I, Cabuy E, Caroni P (2011) Temporally matched subpopulations of selectively interconnected principal neurons in the hippocampus. Nat Neurosci 14:495-504. doi:10.1038/nn.2768

Deller T, Drakew A, Heimrich B, Förster E, Tielsch A, Frotscher M (1999) The hippocampus of the reeler mutant mouse: fiber segregation in area CA1 depends on the position of the postsynaptic target cells. Exp Neurol 156:254-267. doi:10.1006/exnr.1999.7021

Deuchars J, Thomson AM (1996) CA1 pyramid-pyramid connections in rat hippocampus in vitro: dual intracellular recordings with biocytin filling. Neuroscience 74:1009-1018. doi:10.1016/03064522(96)00251-5

Deuel TAS, Liu JS, Corbo JC, Yoo S-Y, Rorke-Adams LB, Walsh CA (2006) Genetic interactions between doublecortin and doublecortin-like kinase in neuronal migration and axon outgrowth. Neuron 49:41-53. doi:10.1016/j.neuron.2005.10.038

Dong H-W, Swanson LW, Chen L, Fanselow MS, Toga AW (2009) Genomic-anatomic evidence for distinct functional domains in hippocampal field CA1. Proc Natl Acad Sci USA 106:1179411799. doi:10.1073/pnas.0812608106

Dumas TC, Powers EC, Tarapore PE, Sapolsky RM (2004) Overexpression of calbindin $\mathrm{D}_{28 \mathrm{k}}$ in dentate gyrus granule cells alters mossy fiber presynaptic function and impairs hippocampaldependent memory. Hippocampus 14:701-709. doi:10.1002/ hipo. 10210

Eichenbaum H, Wiener SI, Shapiro ML, Cohen NJ (1989) The organization of spatial coding in the hippocampus: a study of neural ensemble activity. J Neurosci 9:2764-2775
Enomoto A, Asai N, Namba T, Wang Y, Kato T, Tanaka M, Tatsumi H, Taya S, Tsuboi D, Kuroda K, Kaneko N, Sawamoto K, Miyamoto R, Jijiwa M, Murakumo Y, Sokabe M, Seki T, Kaibuchi K, Takahashi M (2009) Roles of Disrupted-InSchizophrenia 1-interacting protein Girdin in postnatal development of the dentate gyrus. Neuron 63:774-787. doi:10.1016/ j.neuron.2009.08.015

Fan y, Zou B, Ruan Y, Pang Z, Xu ZC (2005) In vivo demonstration of a late depolarizing postsynaptic potential in CA1 pyramidal neurons. J Neurophysiol 93:7598-7609. doi:10.1074/jbc.M110023200

Fanselow MS, Dong H-W (2010) Are the dorsal and ventral hippocampus functionally distinct structures? Neuron 65:7-19. doi:10.1016/j.neuron.2009.11.031

Feng G, Mellor RH, Bernstein M, Keller-Peck C, Nguyen QT, Wallace M, Nerbonne JM, Lichtman JW, Sanes JR (2000) Imaging neuronal subsets in transgenic mice expressing multiple spectral variants of GFP. Neuron 28:41-51. doi:10.1016/ S0896-6273(00)00084-2

Fitch JM, Juraska JM, Washington LW (1989) The dendritic morphology of pyramidal neurons in the rat hippocampal CA3 area I. Cell types. Brain Res 479:105-114. doi:10.1016/00068993(89)91340-1

Frederickson CJ, Koh J-Y, Bush AI (2005) The neurobiology of zinc in health and disease. Nat Rev Neurosci 6:449-462. doi:10.1038/ nrn1671

Freund TF, Buzsáki G (1996) Interneurons of the hippocampus. Hippocampus 6:347-470. doi:10.1002/(SICI)1098-1063(1996)6: 4<347:AID-HIPO1>3.0.CO;2-I

Geneser FA (1987) Distribution of acetylcholinesterase in the hippocampal region of the rabbit: II. Subiculum and hippocampus. J Comp Neurol 262:90-104. doi:10.1002/cne.902620108

Geneser-Jensen FA, Haug FM, Danscher G (1974) Distribution of heavy metals in the hippocampal region of the guinea pig: a light microscope study with Timm's sulfide silver method. Z Zellforsch 147:441-478

Gonzáles JL, Russo CJ, Goldowitz D, Sweet HO, Davisson MT, Walsh CA (1997) Birthdate and cell marker analysis of scrambler: a novel mutation affecting cortical development with a reeler-like phenotype. J Neurosci 17:9204-9211

Goodman JH (1998) Increased vulnerability of superficial CA1 pyramidal cells after microinjection of the indirect excitotoxin $\gamma$ acetylenic GABA (GAG) into the rat dorsal hippocampus. Epilepsia 39(suppl 6):16

Goryunov D, He C-Z, Lin C-S, Leung CL, Liem RKH (2010) Nervous-tissue-specific elimination of microtubule-actin crosslinking factor 1 a results in multiple developmental defects in the mouse brain. Mol Cell Neurosci 44:1-14. doi:10.1016/j.mcn. 2010.01.010

Guo Q, Christakos S, Robinson N, Mattson MP (1998) Calbindin D28 $\mathrm{k}$ blocks the proapoptotic actions of mutant presenilin 1: reduced oxidative stress and preserved mitochondrial function. Proc Natl Acad Sci USA 95:3227-3232

Hirotsune S, Fleck MW, Gambello MJ, Bix GJ, Chen A, Clark GD, Ledbetter DH, McBain CJ, Wynshaw-Boris A (1998) Graded reduction of Pafah1b1 (Lis1) activity results in neuronal migration defects and early embryonic lethality. Nat Genet 19:333-339. doi:10.1038/1221

Hof PR, Rosenthal RE, Fiskum G (1996) Distribution of neurofilament protein and calcium-binding proteins parvalbumin, calbindin, and calretinin in the canine hippocampus. J Chem Neuroanat 11:1-12. doi:10.1016/0891-0618(96)00117-2

Hof PR, Glezer II, Condé F, Flagg A, Rubin MB, Nimchinsky EA, Vogt Weisenhorn DM (1999) Cellular distribution of the calcium-binding proteins parvalbumin, calbindin, and calretinin in the neocortex of mammals: phylogenetic and developmental patterns. J Chem Neuroanat 16:77-116 
Holm IE, Geneser FA (1991) Histochemical demonstration of zinc in the hippocampal region of the domestic pig: II. Subiculum and hippocampus. J Comp Neurol 305:71-82. doi:10.1002/cne. 903050108

Hu H, Li J, Gagen CS, Gray NW, Zhang Z, Qi Y, Zhang P (2011) Conditional knockout of protein O-mannosyltransferase 2 reveals tissue specific roles of O-mannosyl glycosylation in brain development. J Comp Neurol (in press). doi:10.1002/cne. 22572

Ichinohe N, Rockland KS (2005) Zinc-enriched amygdalo- and hippocampo-cortical connections to the inferotemporal cortices in macaque monkey. Neurosci Res 53:57-68. doi:10.1016/ j.neures.2005.06.002

Insausti R, Muñoz M (2001) Cortical projections of non-entorhinal hippocampal formation in the cynomolgus monkey (Macaca fascicularis). Eur J Neurosci 14:435-451. doi:10.1046/j.0953816x.2001.01662.x

Ishida A, Shimazaki K, Terashima T, Kawai N (1994) An electrophysiological and immunocytochemical study of the hippocampus of the reeler mutant mouse. Brain Res 662:60-68. doi: 10.1016/0006-8993(94)90795-1

Ishizuka N, Weber J, Amaral DG (1990) Organization of intrahippocampal projections originating from CA3 pyramidal cells in the rat. J Comp Neurol 295:580-623. doi:10.1002/cne.902950407

Jacobs MS, McFarland WL, Morgane PJ (1979) The anatomy of the brain of the Bottlenose dophin (Tursiops truncatus). Rhinic lobe (rhinencephalon): the archicortex. Brain Res Bull 4(Suppl 1):1-108. doi:10.1016/0361-9230(79)90299-5

Kaibara T, Leung LS (1993) Basal versus apical dendritic long-term potentiation of commissural afferents to hippocampal CA1: a current-source density study. J Neurosci 13:2391-2404

Kajiwara R, Wouterlood FG, Sah A, Boekel AJ, Baks-te Bulte LTG, Witter MP (2008) Convergence of entorhinal and CA3 inputs onto pyramidal neurons and interneurons in hippocampal area CA1 - an anatomical study in the rat. Hippocampus 18:266-280. doi:10.1002/hipo. 20385

Kappeler C, Dhenain M, Phan Din Tuy F, Saillour Y, Marty S, FalletBianco C, Souville I, Souil E, Pinard J-M, Meyer G, EnchaRazavi F, Volk A, Beldjord C, Chelly J, Francis F (2007) Magnetic resonance imaging and histological studies of corpus callosal and hippocampal abnormalities linked to doublecortin deficiency. J Comp Neurol 500:239-254. doi:10.1002/cne.21170

Keays DA, Tian T, Poirier K, Huang GJ, Siebold C, Cleak J, Oliver PL, Fray M, Harvey RJ, Molnár Z, Piñon MC, Dear N, Valdar W, Brown SDM, Davies KE, Rawlins NP, Cowan NJ, Nolan P, Chelly J, Flint J (2007) Mutations in $\alpha$-tubulin cause abnormal neuronal migration in mice and lissencephaly in humans. Cell 128:45-57. doi:10.1016/j.cell.2006.12.017

Klapstein GJ, Vietla S, Lieberman DN, Gray PA, Airaksinen MS, Thoenen H, Meyer M, Mody I (1998) Calbindin- $\mathrm{D}_{28 \mathrm{k}}$ fails to protect hippocampal neurons against ischemia in spite of its cytoplasmic calcium buffering properties: evidence from calbindin- $\mathrm{D}_{28 \mathrm{k}}$ knockout mice. Neuroscience 85:361-373. doi: 10.1016/S0306-4522(97)00632-5

Klausberger T, Somogyi P (2008) Neuronal diversity and temporal dynamics: the unity of hippocampal circuit operations. Science 321:53-57. doi:10.1126/science.1149381

Knowles WD, Funch PG, Schwartzkroin PA (1982) Electrotonic and dye coupling in hippocampal CA1 pyramidal cells in vitro. Neuroscience 7:1713-1722. doi:10.1016/0306-4522(82)90029-X

Koh JY, Choi DW (1994) Zinc toxicity on cultured cortical neurons: involvement of $\mathrm{N}$-methyl-D-aspartate receptors. Neuroscience 60:1049-1057. doi:10.1016/0306-4522(94)90282-8

Krieg WJS (1946) Connections of the cerebral cortex I. The albino rat. B. Structure of the cortical areas. J Comp Neurol 84:277-323. doi:10.1002/cne.900840302
Lai T, Jabaudon D, Molyneaux BJ, Azim E, Arlotta P, Menezes JRL, Macklis JD (2008) SOX5 controls the sequential generation of distinct corticofugal neuron subtypes. Neuron 57:232-247. doi: 10.1016/j.neuron.2007.12.023

Lein ES, Callaway EM, Albright TD, Gage FH (2005) Redefining the boundaries of the hippocampal CA2 subfield in the mouse using gene expression and 3-dimensional reconstruction. J Comp Neurol 485:1-10. doi:10.1002/cne.20426

Leone DP, Srinivasan K, Chen B, Alcamo E, McConnell SK (2008) The determination of projection neuron identity in the developing cerebral cortex. Curr Opin Neurobiol 18:28-35

Leranth C, Ribak CE (1991) Calcium-binding proteins are concentrated in the CA2 field of the monkey hippocampus: a possible key to this region's resistance to epileptic damage. Exp Brain Res 85:129-136. doi:10.1007/BF00229993

Leung LS, Shen B (1995) Long-term potentiation at the apical and basal dendritic synapses of CA1 after local stimulation in behaving rats. J Neurophysiol 73:1938-1946

Lorente de Nó R (1934) Studies on the structure of the cerebral cortex II. Continuation of the study of the Ammonic system. J Psychol Neurol 46:113-177

Masukawa LM, Bernardo LS, Price DA (1982) Variations in electrophysiological properties of hippocampal neurons in different subfields. Brain Res 242:341-344. doi:10.1016/ 0006-8993(82)90320-1

Mattson MP, Rychlik B, Chu C, Christakos S (1991) Evidence for calcium-reducing and excito-protective roles for the calciumbinding protein calbindin- $28 \mathrm{k}$ in cultured hippocampal neurons. Neuron 6:41-51. doi:10.1016/0896-6273(91)90120-O

McGeorge AJ, Faull RLM (1989) The organization of the projection from the cerebral cortex to the striatum in the rat. Neuroscience 29:503-537. doi:10.1016/0306-4522(89)90128-0

Mercer A, Bannister AP, Thomson AM (2006) Electrical coupling between pyramidal cells in adult cortical regions. Brain Cell Biol 35:13-27. doi:10.1007/s11068-006-9005-9

Mitchelmore C, Kjærulff KM, Pedersen HC, Nielsen JV, Rasmussen TE, Fisker MF, Finsen B, Pedersen KM, Jensen NA (2002) Characterization of two novel nuclear BTB/POZ domain zinc finger isoforms. J Biol Chem 277:7598-7609. doi:10.1074/jbc. M110023200

Morris ME, Baimbridge KG, El-Beheiry H, Obrocea GV, Rosen AS (1995) Correlation of anoxic neuronal responses and calbindin$\mathrm{D}_{28 \mathrm{k}}$ localization in stratum pyramidale of rat hippocampus. Hippocampus 5:25-39. doi:10.1002/hipo.450050105

Nakamura NH, Fukunaga M, Akama KT, Soga T, Ogawa S, Pavlides C (2010) Hippocampal cells encode places by forming small anatomical clusters. Neuroscience 166:994-1007. doi:10.1016/ j.neuroscience.2009.12.069

Namura S, Takada M, Kikuchi H, Mizuno N (1994) Topographical organization of subicular neurons projecting to subcortical regions. Brain Res Bull 35:221-231. doi:10.1016/0361-9230 (94) $90126-0$

Nielsen JV, Nielsen FH, Ismail R, Noraberg J, Jensen NA (2007) Hippocampus-like corticoneurogenesis induced by two isoforms of the BTB-zinc finger gene Zbtb20 in mice. Development 134:1133-1140. doi:10.1242/dev.000265

Nielsen JV, Blom JB, Noraberg J, Jensen NA (2010) Zbtb20-induced CA1 pyramidal neuron development and area enlargement in the cerebral midline cortex of mice. Cereb Cortex 20:1904-1914. doi:10.1093/cercor/bhp261

Nosten-Bertrand M, Kappeler C, Dinocourt C, Denis C, Germain J, Phan Dinh Tuy F, Verstraeten S, Alvarez C, Métin C, Chelly J, Giros B, Miles R, Depaulis A, Francis F (2008) Epilepsy in Dcx knockout mice associated with discrete lamination defects and enhanced excitability in the hippocampus. PLoS ONE 3:e2473. doi:10.1371/journal.pone.0002473 
Nowakowski RS (1984) The mode of inheritance of a defect in lamination in the hippocampus of BALB/c mice. J Neurogenetics $1: 249-258$

Nowakowski RS, Davis TL (1985) Dendritic arbors and dendritic excrescences of abnormally positioned neurons in area CA3c of mice carrying the mutation "hippocampal lamination defect". J Comp Neurol 239:267-275. doi:10.1002/cne.902390303

Núñez A, García-Austt E, Buño W (1990) In vivo electrophysiological analysis of lucifer yellow-coupled hippocampal pyramids. Exp Neurol 108:76-82. doi:10.1016/0014-4886(90)90010-P

Ohshima T, Ogawa M, Veeranna, Hirasawa M, Longenecker G, Ishiguro K, Pant HC, Brady RO, Kulkarni AB, Mikoshiba K (2001) Synergistic contributions of cyclin-dependant kinase 5/p35 and reelin/Dab1 to the positioning of cortical neurons in the developing mouse brain. Proc Natl Acad Sci USA 98:2764-2769. doi:10.1073/pnas.051628498

Ohshima T, Ogura H, Tomizawa K, Hayashi K, Suzuki H, Saito T, Kamei H, Nishi A, Bibb JA, Hisanaga S-I, Matsui H, Mikoshiba $\mathrm{K}$ (2005) Impairment of hippocampal long-term depression and defective spatial learning and memory in $\mathrm{p} 35^{-/-}$mice. $\mathrm{J}$ Neurochem 94:917-925. doi:10.1111/j.1471-4159.2005.03233.x

Paoletti P, Perin-Dureau F, Fayyazuddin A, le Goff AL, Callebaut I, Neyton J (2000) Molecular organization of a zinc-binding $\mathrm{N}$-terminal modulatory domain in a NMDA receptor unit. Neuron 28:911-925. doi:10.1016/S0896-6273(00)00163-X

Paoletti P, Vergnano AM, Barbour B, Casado M (2009) Zinc at glutamatergic synapses. Neuroscience 158:126-136. doi: 10.1016/j.neuroscience.2008.01.061

Paxinos G, Watson C (1986) The rat brain in stereotaxic coordinates, 2nd edn. Academic Press, Sydney

Perez Velazquez JL, Carlen PL (2000) Gap junctions, synchrony and seizures. Trends Neurosci 23:68-74. doi:10.1016/S0166-2236 (99)01497-6

Perez-Velazquez JL, Valiante TA, Carlen PL (1994) Modulation of gap junctional mechanisms during calcium-free induced field burst activity: a possible role for electrotonic coupling in epileptogenesis. J Neurosci 14:4308-4317

Pramparo T, Youn YH, Yingling J, Hirotsune S, Wynshaw-Boris A (2010) Novel embryonic neuronal migration and proliferation defects in Dcx mutant mice are exacerbated by Lis1 reduction. J Neurosci 30:3002-3012. doi:10.1523/JNEUROSCI.485109.2010

Rachline J, Perin-Dureau F, Le Goff A, Neyton J, Paoletti P (2005) The micromolar zinc-binding domain on the NMDA receptor subunit NR2B. J Neurosci 25:308-317. doi:10.1523/ JNEUROSCI.3967-04.2005

Rami A, Bréhier A, Thomasset M, Rabié A (1987a) Cholecalcin (28$\mathrm{kDa}$ calcium-binding protein) in the rat hippocampus: development in normal animals and in altered thyroid states. Dev Biol 124:228-238. doi:10.1016/0012-1606(87)90474-X

Rami A, Bréhier A, Thomasset M, Rabié A (1987b) The comparative immunocytochemical distribution of $28 \mathrm{kDa}$ cholecalcin $(\mathrm{CaBP})$ in the hippocampus of rat, guinea pig and hedgehog. Brain Res 422:149-153. doi:10.1016/0006-8993(87)90549-X

Ramón y Cajal S (1893) Estructura del asta de Ammon. Ann Soc Esp Hist Nat Madr 22:53-114. Ramón y Cajal S (1968) The structure of Ammon's horn (trans: Kraft LM). Charles C Thomas, Springfield

Risold PY, Swanson LW (1996) Structural evidence for functional domains in the rat hippocampus. Science 272:1484-1486. doi: 10.1126/science. 272.5267 .1484

Roberts AC, Tomic DL, Parkinson CH, Roeling TA, Cutter DJ, Robbins TW, Everitt BJ (2007) Forebrain connectivity of the prefrontal cortex in the marmoset monkey (Callithrix jacchus): an anterograde and retrograde tract-tracing study. J Comp Neurol 502:86-112. doi:10.1002/cne.21300
Rose M (1926) Der Allocortex bei Tier und Mensch I. Teil. J Psychol Neurol 34:1-111

Rosene DL, van Hoesen GW (1987) The hippocampal formation of the primate brain. A review of some comparative aspects of cytoarchitecture and connections. In: Jones EG, Peters A (eds) Cerebral cortex, vol 6. Plenum, New York, pp 345-456

Ruan Y-W, Zou B, Fan Y, Li Y, Lin N, Zhang Y, Xu ZC (2007) Morphological heterogeneity of CA1 pyramidal neurons in response to ischemia. J Neurosci Res 85:193-204. doi: 10.1002/jnr.21101

Schaffer K (1892) Beitrag zur Histologie der Ammonshornformation. Arch Mikrosk Anat 39:611-632

Scharfman HE, Schwartzkroin PA (1989) Protection of dentate hilar cells from prolonged stimulation by intracellular calcium chelation. Science 246:257-260. doi:10.1126/science.2508225

Schlessinger AR, Cowan WM, Swanson LW (1978) The time of origin of neurons in Ammon's horn and the associated retrohippocampal fields. Anat Embryol 154:153-173. doi:10.1007/BF00304660

Schmitz D, Schuchmann S, Fisahn A, Draguhn A, Buhl E, PetraschParwez E, Dermietzel R, Heinemann U, Traub RD (2001) Axoaxonal coupling: a novel mechanism for ultrafast neuronal communication. Neuron 31:831-840. doi:10.1016/S0896-6273 (01)00410-X

Scorza CA, Araujo BH, Leite LA, Torres LB, Otalora LF, Oliveira MS, Garrido-Sanabria ER, Cavalheiro EA (2011) Morphological and electrophysiological properties of pyramidal-like neurons in the stratum oriens of Cornu ammonis 1 and Cornu ammonis 2 area of Proechimys. Neuroscience 177:252-268. doi:10.1016/ j.neuroscience.2010.12.054

Sekiguchi M, Shimai K, Guo H, Nowakowski RS (1992) Cytoarchitectonic abnormalities in hippocampal formation and cerebellum of dreher mutant mouse. Dev Brain Res 67:105-112. doi: 10.1016/0165-3806(92)90030-Z

Sekiguchi M, Nowakowski RS, Nagato Y, Tanaka O, Guo H, Madako M, Abe H (1995) Morphological abnormalities in the hippocampus of the weaver mutant mouse. Brain Res 696:262-267. doi:10.1016/0006-8993(95)00974-U

Senior TJ, Huxter JR, Allen K, O’Neill J, Csicsvari J (2008) Gamma oscillatory firing reveals distinct populations of pyramidal cells in the CA1 region of the hippocampus. J Neurosci 28:22742286. doi:10.1523/JNEUROSCI.4669-07.2008

Seress L, Gulyás AI, Freund TF (1991) Parvalbumin- and calbindin $\mathrm{D}_{28 \mathrm{k}}$-immunoreactive neurons in the hippocampal formation of the macaque monkey. J Comp Neurol 313:162-177. doi: 10.1002/cne.903130112

Seress L, Gulyas AI, Freund TF (1992) Pyramidal neurons are immunoreactive for calbindin $\mathrm{D}_{28 \mathrm{k}}$ in the CA1 subfield of the human hippocampus. Neurosci Lett 138:257-260. doi:10.1016/ 0304-3940(92)90928-Z

Seress L, Gulyás AI, Ferrer I, Tunon T, Soriano E, Freund TF (1993) Distribution, morphological features, and synaptic connections of parvalbumin- and calbindin $\mathrm{D}_{28 \mathrm{k}}$-immunoreactive neurons in the human hippocampal formation. J Comp Neurol 337:208230. doi:10.1002/cne.903370204

Shepherd TM, Özarslan E, Yachnis AT, King MA, Blackband SJ (2007) Diffusion tensor microscopy indicates the cytoarchitectural basis for diffusion anisotropy in the human hippocampus. Am J Neuroradiol 29:958-964

Slomianka L (1992) Neurons of origin of zinc-containing pathways and the distribution of zinc-containing boutons in the hippocampal region of the rat. Neuroscience 48:252-325. doi: 10.1016/0306-4522(92)90494-M

Slomianka L, Geneser FA (1991) Distribution of acetylcholinesterase in the hippocampal region of the mouse: II. Subiculum and hippocampus. J Comp Neurol 312:525-536. doi:10.1002/cne. 903120404 
Slomianka L, Geneser FA (1997) Postnatal development of zinccontaining cells and neuropil in the hippocampal region of the mouse. Hippocampus 7:321-340. doi:10.1002/(SICI)10981063(1997)7:3<321:AID-HIPO7>3.0.CO;2-N

Slomianka L, Ernst E, Ostergaard K (1997) Zinc-containing neurons are distinct from GABAergic neurons in the telencephalon of the rat. Anat Embryol 195:165-174. doi:10.1007/s004290050035

Sloviter RS (1989) Calcium-binding protein (calbindin- $\mathrm{D}_{28 \mathrm{k}}$ ) immunocytochemistry: localization in the rat hippocampus with specific reference to the selective vulnerability of hippocampal neurons to seizure activity. J Comp Neurol 280:183-196. doi: 10.1002/cne.902800203

Sloviter RS, Sollas AL, Barbaro NM, Laxer KD (1991) Calciumbinding protein (calbindin-D28K) and parvalbumin immunocytochemistry in the normal and epileptic human hippocampus. J Comp Neurol 308:381-396. doi:10.1002/cne.903080306

Sloviter RS, Kudrimoti HS, Laxer KD, Barbaro NM, Chan S, Hirsch LJ, Goodman RR, Pedley TA (2004) "Tectonic" hippocampal malformations in patients with temporal lobe epilepsy. Epilepsy Res 59:123-153. doi:10.1016/j.eplepsyres.2004.04.001

Smart IHM (1982) Radial unit analysis of hippocampal histogenesis in the mouse. J Anat 135:763-793

Sørensen JC, Tønder N, Slomianka L (1993) Zinc-positive afferents to the rat septum originate from distinct subpopulations of zinccontaining neurons in hippocampal areas and layers. A combined fluoro-gold tracing and histochemical study. Anat Embryol 188:107-115. doi:10.1007/BF00186245

Sørensen JC, Slomianka L, Christensen J, Zimmer J (1995) Zinccontaining telencephalic connections to the rat striatum: a combined Fluoro-Gold tracing and histochemical study. Exp Brain Res 105:370-381. doi:10.1007/BF00233037

Stanfield BB, Cowan WM (1979a) The development of the hippocampus and dentate gyrus in normal and reeler mice. J Comp Neurol 185:423-460. doi:10.1002/cne.901850303

Stanfield BB, Cowan WM (1979b) The morphology of the hippocampus and dentate gyrus in normal and reeler mice. J Comp Neurol 185:393-422. doi:10.1002/cne.901850302

Stephan H (1975) Allocortex, vol IV/9. Handbuch der mikroskopischen Anatomie des Menschen. Springer, Berlin

Strekalova T, Zörner B, Zacher C, Sadovska G, Herdegen T, Gass P (2003) Memory retrieval after contextual fear conditioning induces c-Fos and JunB expression in CA1 hippocampus. Genes Brain Behav 2:3-10. doi:10.1034/j.1601-183X.2003.00001.x

Swanson LW (1992) Brain maps. Structure of the rat brain. Elsevier, Amsterdam

Swanson LW, Wyss JM, Cowan WM (1978) An autoradiographic study of the organization of intrahippocampal association pathways in the rat. J Comp Neurol 181:681-716. doi: 10.1002/cne.901810402

Swanson LW, Sawchenko PE, Cowan WM (1980) Evidence that the commissural, associational and septal projections of the regio inferior of the hippocampus arise from the same neurons. Brain Res 197:207-212. doi:10.1016/0006-8993(80)90446-1

Tabuchi E, Ono T, Nishijo H, Endo S, Kuze S (1995) Ischemic neuronal damage specific to monkey hippocampus: histological investigation. Brain Res Bull 37:73-87. doi:10.1016/03619230(94)00262-2

Takeda S, Kondo M, Sasaki J, Kurahashi H, Kano H, Arai K, Misaki K, Fukui T, Kobayashi K, Tachikawa M, Imamura M, Nakamura
Y, Shimizu T, Murakami T, Sunada Y, Fujikado T, Matsumura $\mathrm{K}$, Terashima $\mathrm{T}$, Toda $\mathrm{T}$ (2003) Fukutin is required for maintenance of muscle integrity, cortical histiogenesis and normal eye development. Human Mol Genet 12:1449-1459. doi: $10.1093 / \mathrm{hmg} / \mathrm{ddg} 153$

Tamamaki N, Nojyo Y (1991) Disposition of the slab-like modules formed by axon branches originating from single CA1 pyramidal neurons in the rat hippocampus. J Comp Neurol 291:509-519. doi:10.1002/cne. 902910403

Tamamaki N, Nojyo Y (1995) Preservation of topography in the connections between the subiculum, field CA1, and the entorhinal cortex of the rat. J Comp Neurol 353:379-390. doi: 10.1002/cne.903530306

Tamamaki N, Abe K, Nojyo Y (1987) Columnar organization in the subiculum formed by axon branches originating from single $\mathrm{CA}_{1}$ pyramidal neurons in the rat hippocampus. Brain Res 412:156-160. doi:10.1016/0006-8993(87)91452-1

Thompson CL, Pathak SD, Jeromin A, Ng LL, MacPherson CR, Mortrud MT, Cusick A, Riley ZL, Sunkin SM, Bernard A, Puchalski RB, Gage FH, Jones AR, Bajic VB, Hawrylycz MJ, Lein ES (2008) Genomic anatomy of the hippocampus. Neuron 60:1010-1021. doi:10.1016/j.neuron.2008.12.008

Towfighi J, Housman C, Brucklacher R, Vannucci RC (2004) Neuropathology of seizures in the immature rabbit. Dev Brain Res 152:143-152. doi:10.1016/j.devbrainres.2004.06.009

Tronson NC, Schrick C, Guzman YF, Huh KH, Srivastava DP, Penzes P, Guedea AL, Gao C, Radulovic J (2009) Segregated populations of hippocampal principal CA1 neurons mediating conditioning and extinction of contextual fear. J Neurosci 29:33873394. doi:10.1523/JNEUROSCI.5619-08.2009

van Groen T, Wyss JM (1988) Species differences in hippocampal commissural connections: studies in rat, guinea pig, rabbit, and cat. J Comp Neurol 267:322-334. doi:10.1002/cne.902670303

Vaughn JE, Matthews DA, Barber RP, Wimer CC, Wimer RE (1977) Genetically-associated variations in the development of hippocampal pyramidal neurons may produce differences in mossy fiber connectivity. J Comp Neurol 173:41-52. doi:10.1002/ cne.901730104

Wang Y, Baraban SC (2008) Aberrant dentate gyrus cytoarchitecture and fiber lamination in Lis1 mutant mice. Hippocampus 18:758-765. doi:10.1002/hipo.20434

Witter MP, Ostendorf RH, Groenewegen HJ (1990) Heterogeneity in the dorsal subiculum of the rat. Distinct neuronal zones project to different cortical and subcortical targets. Eur $\mathrm{J}$ Neurosci 2:718-725. doi:10.1111/j.1460-9568.1990.tb00462.x

Wu HQ, Schwarcz R (1998) Focal microinjection of $\gamma$-acetylenic GABA in the rat entorhinal cortex: behavioral and electroencephalographic abnormalities and preferential neuron loss in layer III. Exp Neurol 153:203-213. doi:10.1006/exnr.1998.6908

Xie Z, Ma X-H, Ji W, Zhou G, Lu Y, Xiang Z, Wang YX, Zhang L, $\mathrm{Hu}$ Y, Ding Y-Q, Zhang WJ (2010) Zbtb20 is essential for the specification of CA1 field identity in the developing hippocampus. Proc Natl Acad Sci USA 107:6510-6515. doi:10.1073/pnas. 0912315107

Yukie M (2000) Connections between the medial temporal cortex and the CA1 subfield of the hippocampal formation of the Japanese monkey (Macaca fuscata). J Comp Neurol 423:282-298. doi: 10.1002/1096-9861(20000724)423:2<282:AID-CNE7>3.0.CO;2-Z 